\title{
THE SCREECH OWL: ITS LIFE HISTORY AND POPULATION ECOLOGY IN NORTHERN OHIO
}

\author{
By \\ Laurel F. VanCamp, Wildlife Naturalist \\ Ohio Department of Natural Resources \\ Division of Wildlife \\ Charles J. Henny, Research Biologist \\ Migratory Bird and Habitat Research Laboratory \\ U.S. Fish and Wildlife Service
}

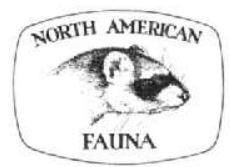

NUMBER 71 


\section{UNITED STATES DEPARTMENT OF THE INTERIOR}

FISH AND WILDLIFE SERVICE

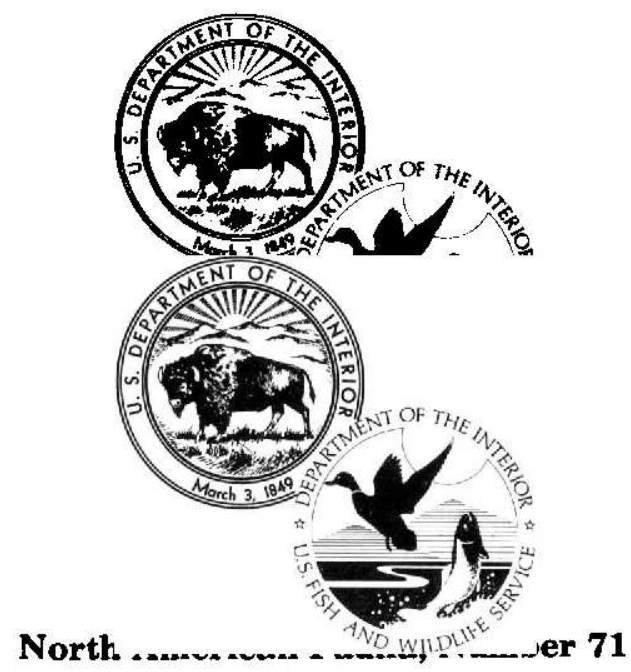

\section{Published by}

FISH AND WILDLIFE SERVICE 1975 


\section{Contents}

Page

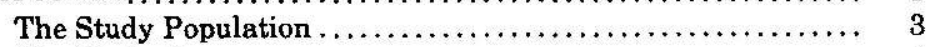

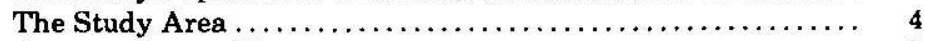

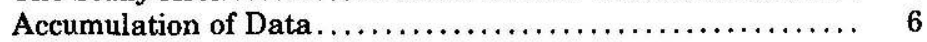

TAXONOMY $\ldots \ldots \ldots \ldots \ldots \ldots \ldots \ldots \ldots \ldots \ldots \ldots \ldots \ldots, \quad 8$

FOOD HABITS $\ldots \ldots \ldots \ldots \ldots \ldots \ldots \ldots \ldots \ldots \ldots \ldots \ldots \ldots \ldots \ldots \ldots \ldots, \quad 9$

During the Nesting Season.......................... 10

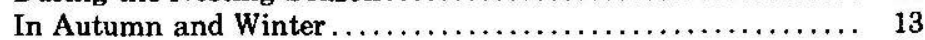

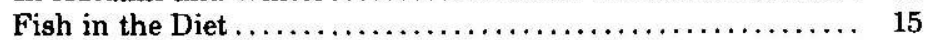

Seasonal Variation $\ldots \ldots \ldots \ldots \ldots \ldots \ldots \ldots \ldots \ldots \ldots, 16$

MigRATION AND DisPERSAL $\ldots \ldots \ldots \ldots \ldots \ldots \ldots \ldots \ldots \ldots \ldots, 18$

Dispersal Related to Age and Season .................. 19

Dispersal Distance .............................. $\quad 20$

Directional Pattern of Dispersal ........................ 22

Records of Individual Birds $\ldots \ldots \ldots \ldots \ldots \ldots \ldots \ldots \ldots, 24$

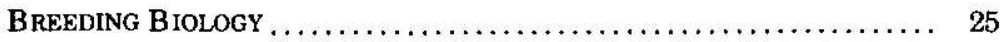

Breeding Season $\ldots \ldots \ldots \ldots \ldots \ldots \ldots \ldots \ldots \ldots \ldots \ldots \ldots \ldots, 25$

Clutch Size $\ldots \ldots \ldots \ldots \ldots \ldots \ldots \ldots \ldots \ldots \ldots \ldots \ldots \ldots \ldots \ldots \ldots \ldots, 26$

Nesting Success and Fledging Rates $\ldots \ldots \ldots \ldots \ldots \ldots \ldots, 27$

Causes of Nest Loss............................... 32

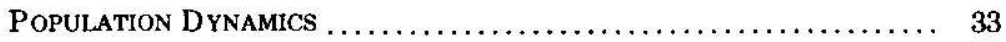

Sex Ratio in Population ............................ 33

Mortality Rates $\ldots \ldots \ldots \ldots \ldots \ldots \ldots \ldots \ldots \ldots \ldots \ldots \ldots, \quad 33$

Causes of Postfledging Mortality ...................... 35

Age at Sexual Maturity $\ldots \ldots \ldots \ldots \ldots \ldots \ldots \ldots \ldots \ldots \ldots, 37$

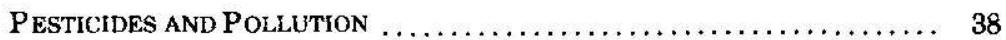

Eggshell Thinning $\ldots \ldots \ldots \ldots \ldots \ldots \ldots \ldots \ldots \ldots \ldots \ldots \ldots \ldots, \quad 39$

Residue Levels in Eggs $\ldots \ldots \ldots \ldots \ldots \ldots \ldots \ldots \ldots \ldots \ldots, 40$

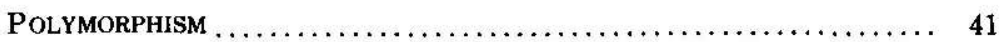

Annual Variation in Color Phase Ratios................. 43

Sex, Age, and Color Phase $\ldots \ldots \ldots \ldots \ldots \ldots \ldots \ldots \ldots \ldots, 47$

Genetic Hypotheses ............................. 49

Brood Size and Color Phase $\ldots \ldots \ldots \ldots \ldots \ldots \ldots \ldots \ldots, \quad 54$

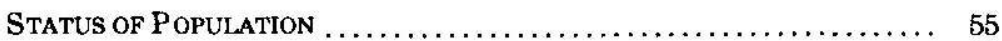

Index to Annual Abundance $\ldots \ldots \ldots \ldots \ldots \ldots \ldots \ldots \ldots, \quad 55$

Life Equation Approach $\ldots \ldots \ldots \ldots \ldots \ldots \ldots \ldots \ldots \ldots \ldots, \quad 58$

Summary of Status . . . . . . . . . . . . . . . .

(Cont'd) 
CONTENTS (Cont'd)

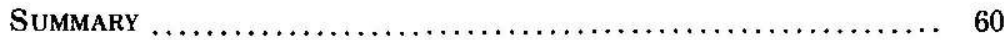

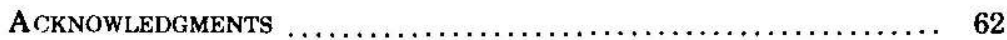

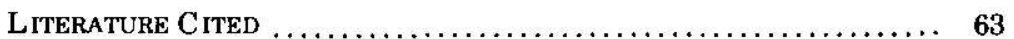

\section{Illustrations}

\section{FIGURE}

Frontispiece, The cryptic coloration of the gray phase of the

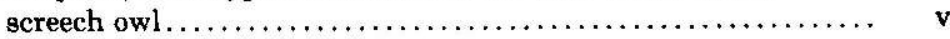

1. A nest box is checked on the study area $\ldots \ldots \ldots \ldots \ldots \ldots \ldots, 1$

2. The four-county study area in northern Ohio.............. 2

3. An improved nest box which was used on the study area

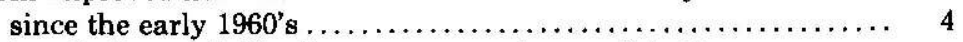

4. A typical open field adjacent to a wooden creek bottom in the study area $\ldots \ldots \ldots \ldots \ldots \ldots \ldots \ldots \ldots \ldots \ldots \ldots, \quad 6$

5. The directional preference of screech owl dispersal in the northeastern United States....................... 23

6. A banded screech owl being released at its nest box by

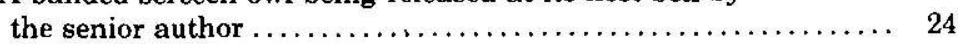

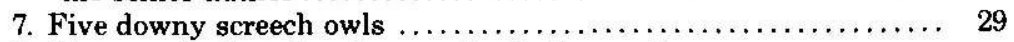

8. Changes in the color phase ratios in the northern Ohio study area, $1944-73 \ldots \ldots \ldots \ldots \ldots \ldots \ldots \ldots \ldots \ldots, 43$

NOTE: For additional copies, write C. J. Henny, Building 16, Federal Center, Denver, Colorado 80225. 


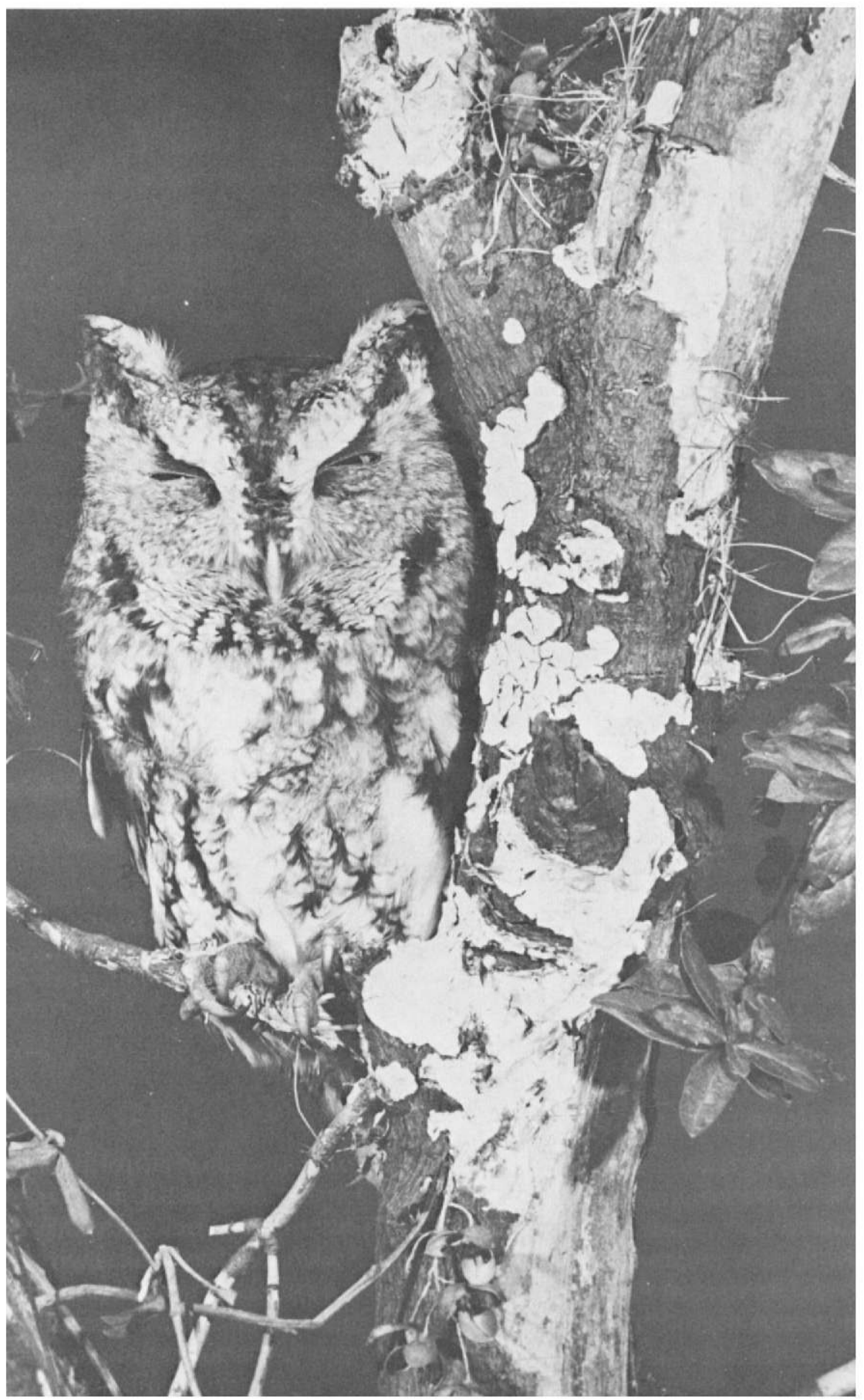

Frontispiece-The cryptic coloration of the gray phase of the screech owl (photo courtesy of G. Ronald Austing). 



\section{INTRODUCTION}

The screech owl (Otus asio) is native to North America and breeds throughout the United States and in portions of Canada and Mexico. It is a small owl, $20 \mathrm{~cm}(8 \mathrm{in})$ in length from the tip of the bill to the tip of the tail, with a wing span of $56 \mathrm{~cm}$ ( $22 \mathrm{in}$ ); it has yellow eyes and prominent ear tufts (see Frontispiece). Although the species is common throughout much of North America, it has not been studied intensively, particularly over a long period. The published literature is concerned mostly with food habits, color phase, taxonomy, and miscellaneous observations. Breeding biology and population dynamics have received little attention.

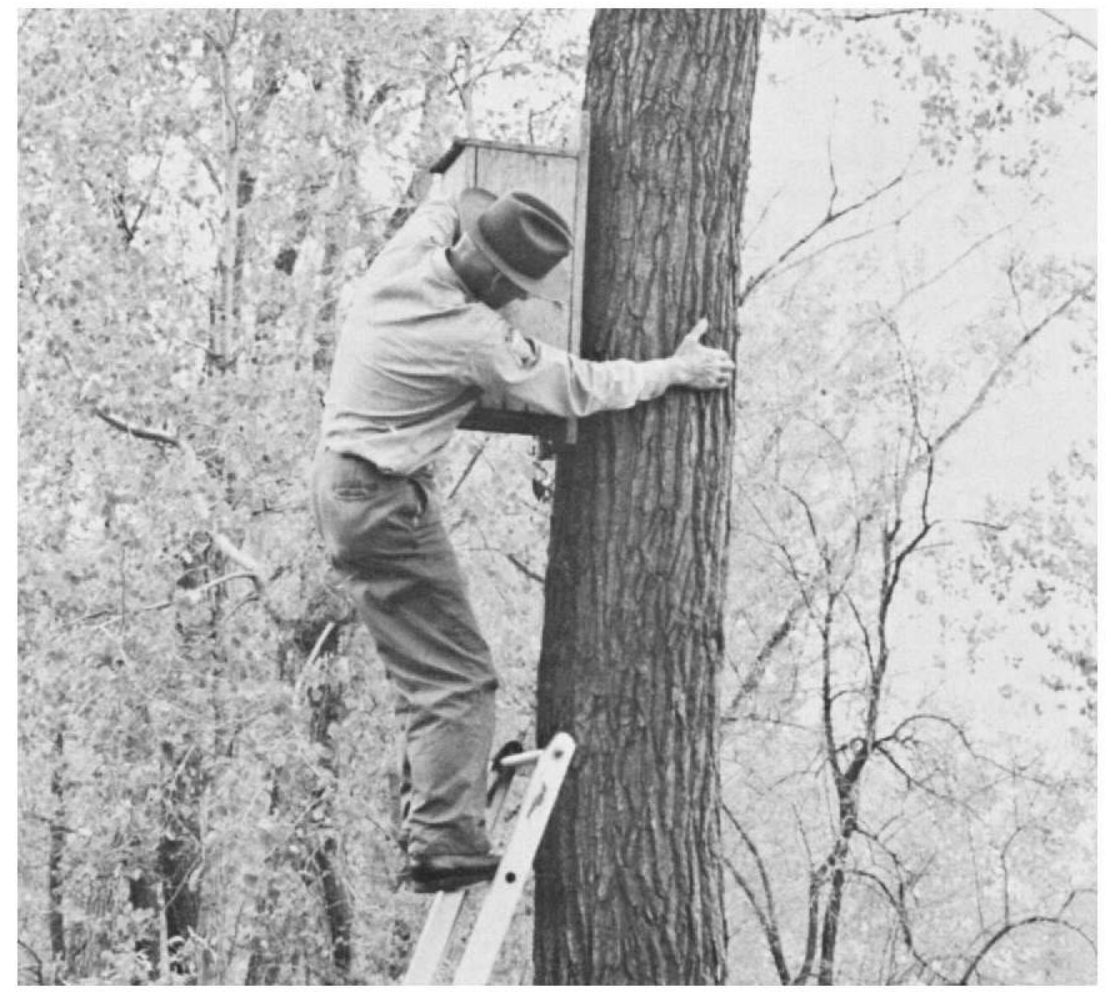

Fig. 1.-A nest box is checked on the study area (photo courtesy of George Laycock). 


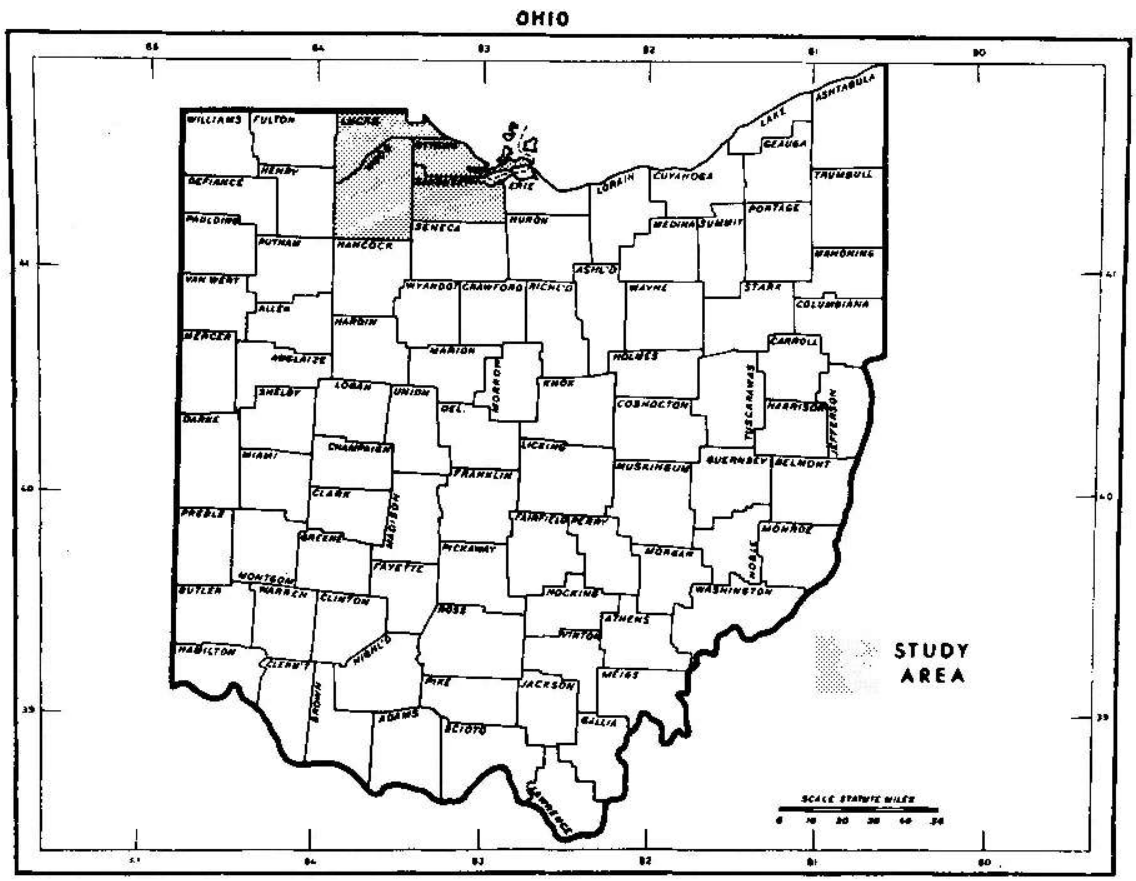

Fig. 2.-The four-county study area in northern Ohio.

This report presents the basic life history and population information about screech owls in northern Ohio over a 30-yr period. The owls studied were nesting in boxes (Fig. 1) established for wood ducks ( Aix sponsa) along rivers, creeks, and marshes in a four-county area (Ottawa, Sandusky, Wood, and Lucas Counties) near Lake Erie (Fig. 2). No special trapping techniques were required as the screech owls readily used these nesting boxes and could be easily captured while in them. More than 3,000 owls were captured and banded; 500 were recaptured after the initial banding, some 10 or 15 times. This process provided a large quanity of basic information for this report.

The banding data provided useful information on dispersal, mortality, and age at sexual maturity; in several instances, however, the data were supplemented by banding data of other workers in the area north and east of Missouri. More than 500 nesting attempts by the screech owls were recorded, and 53 different species of birds were listed as food items in the nest boxes during the nesting season. Supplemental information on the 
seasonal food habits of the screech owl was obtained from food habit cards filed at the Patuxent Wildlife Research Center, Laurel, Maryland.

The senior author initiated the study in 1944 and collected the field data through 1973. The junior author analyzed the data, wrote the report and coordinated the pesticide phase of the study with the Patuxent Wildlife Research Center in 1973. We have also brought together the relevant literature on the screech owl with emphasis on population ecology. This subject may be particularly timely since McLane and Hall (1972) showed that a low dietary dosage of DDE (a chlorinated hydrocarbon pesticide) causes eggshell thinning under laboratory conditions. Eggshell thinning has been associated with declines of many raptorial and fish-eating birds in both western Europe and North America (Ratcliffe 1967; Hickey and Anderson 1968; Lockie et al. 1969; Hickey 1969). Furthermore, the screech owl data have been subjected to a modeling process (Henny et al. 1970) to determine population parameters for the species in northern Ohio.

\section{The Study Population}

The screech owl population reported herein is one that nested in wood duck boxes in northern Ohio between 1944 and 1973. The fact that the birds were using artificial nesting structures may cause a bias in a portion of the findings, particularly in terms of population trends (indices) and annual recruitment rates. For example, trends in population numbers should not be based on the percentage of the nest boxes occupied each year because the nest boxes were always placed in suitable habitat. A population reduction from the loss of habitat would be undetected by such an approach. Our population index most likely represents the annual population nesting in suitable habitat. We believe, however, that most of the other findings presented in this paper are representative of the wild screech owl population in the study area, and, as such, were not biased by the type of nest site used.

Screech owls began using the nest boxes in northern Ohio much earlier than wood ducks. In fact, we have found wood ducks nesting in boxes after young screech owls have fledged. It is our subjective assessment that screech owls keep starlings (Sturnus vulgaris), which are much more competitive than the owls, out of the nest boxes within the owls' feeding areas. Upon occasion, starlings will bury wood duck eggs under their nesting material and cause the hen to desert. We therefore contend that wood duck nesting success is enhanced by the presence of screech owl nesting. Adequate numbers of nest boxes should be provided for both species. 


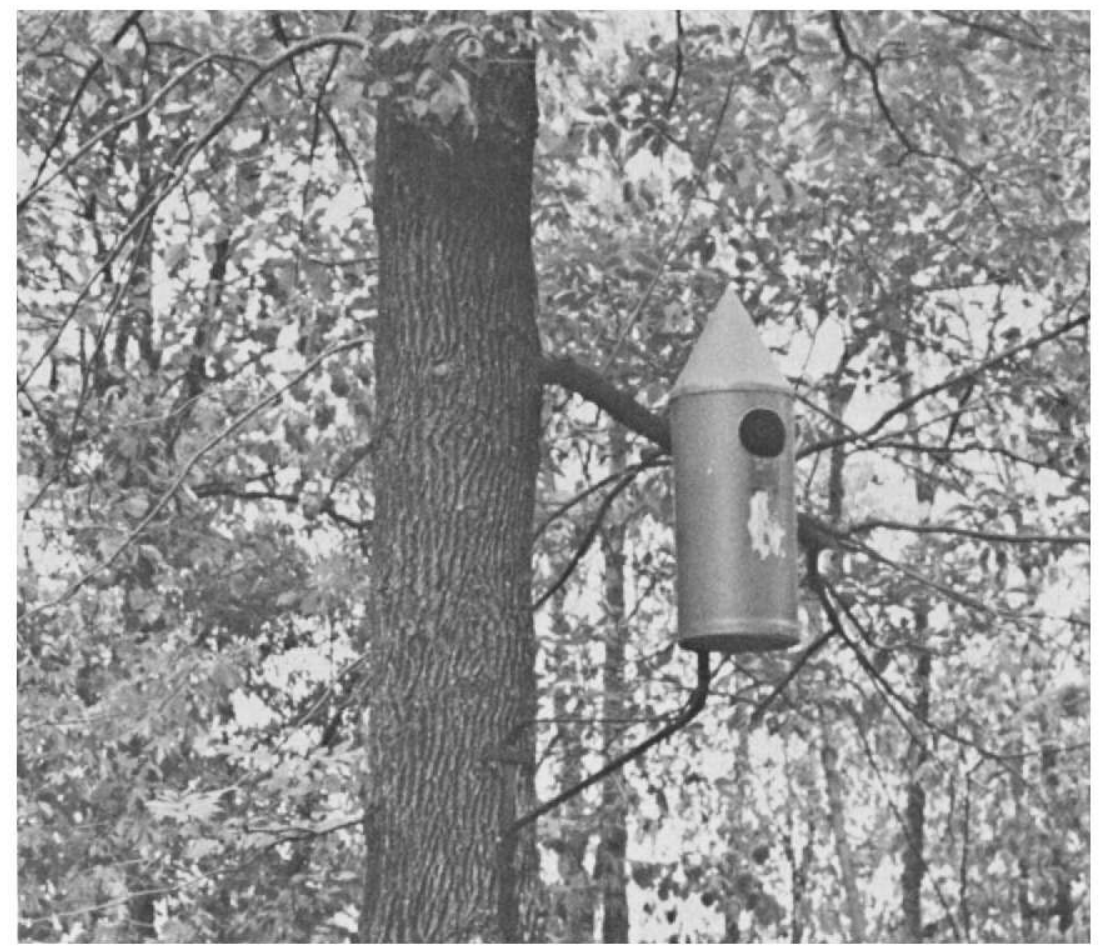

Fig. 3.-An improved nest box which was used on the study area since the early 1960 's. One hundred of this type of box were available annually during the last decade.

Beginning early in the 1960 's, most of the nest boxes were made with cylinders shaped like rockets (after the design of Bellrose 1955; Fig. 3). The owls used the boxes for nesting, roosting, and feeding.

\section{The Study Area}

Nearly all of the study area lies within the boundaries of what was called the "Black Swamp" during the early annals of North American history. The Black Swamp was drained late in the nineteenth century and is so transformed that an observer would have difficulty in estimating its former extent. Mayfield (1962) discussed changes in the natural history of the area since the coming of the white man, but indicated that agriculture had modified this region long before a competent naturalist had studied the plants and animals. 
From the beginning of settlement in the Black Swamp (circa 1820 ), the entire agricultural system revolved around corn. Most of the conversion to agricultural land in northwestern Ohio took place after 1850 and continued until the turn of the century (Kaatz 1953). Within a few decades, the Swamp was transformed into one of the most productive agricultural regions in Ohio. By 1930, the Black Swamp was the most completely cropped area in the State (Sitterley and Falconer 1933). Today, like 60 or 70 yr ago, the Black Swamp lands are dominantly rural. Although there are urban and industrial areas around Toledo and other smaller cities, the rural scene prevails elsewhere.

The Black Swamp, like most dense, unbroken forests, was not rich in wildlife (Kaatz 1953). Information on bird populations is scarce; however, it is almost certain that many of the species common at the time of settlement have been extirpated or greatly reduced in numbers. Conversely, some of the most common birds today were rare or nonexistant in the area when the first settlers arrived. Some species that are abundant today prefer nesting sites provided by the structures of modern man and are scarcely to be found in natural sites. Mayfield (1962) reviews the changed status of a number of bird species. It is unclear how or to what extent habitat changes have influenced the status of screech owls. In reference to central Ohio, Trautman (1940:275-276) reported, "Statements by hunters and farmers who were well acquainted with the screech owl indicate that before 1900 this species was decidedly uncommon in the area and that with the removal of most of the forests and the decrease in numbers, or extirpation, of barred and horned owls, the screech owl became increasingly numerous. These statements agree with my studies." Furthermore, Bent (1938:246) states, "The screech owl also has been known to nest frequently, even regularly, in cavities in trees close to houses in towns and cities, thus showing more confidence in human beings than most other owls show."

An illustration of an open field adjacent to a wooded creek bottom where several screech owls nested annually is shown in Fig. 4. The loss of forested land in the four-county study area-12\% between 1958 and 1967 (Table 1)-is continuing. Farmers are using more and more of their land each year for agriculture. The wooded creek bottom and woodlots are being cleared for mechanized agriculture. Only $7.6 \%$ of the study area was classified as forested land in 1967 . This contrasts with about $90 \%$ of the area being forested in 1853 (Diller 1962). In 1967, the four-county area consisted of $85.2 \%$ cropland, $1.9 \%$ pasture, $7.6 \%$ forested, and $5.3 \%$ other land (Anon. 1971). The most important agricultural crops are corn and soybeans. 


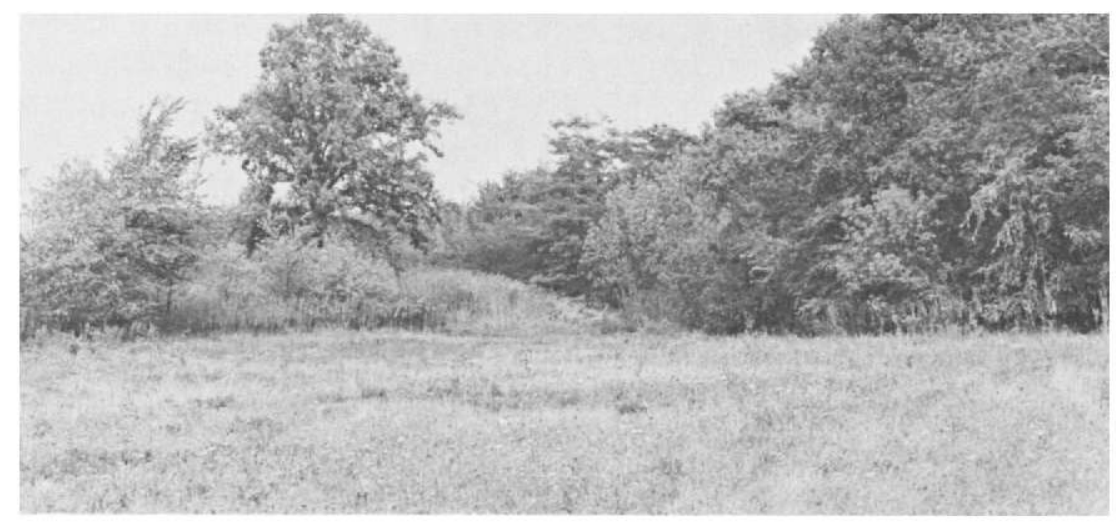

Fig. 4.-A typical open field adjacent to a wooded creek bottom in the study area.

Table 1. The forest area in the four-county study area in northern Ohio, 1958 vs. 1967 (from Anonymous 1971).

\begin{tabular}{lcc}
\hline & \multicolumn{2}{c}{ Forest area (acres) } \\
\cline { 2 - 3 } County & $\mathbf{1 9 5 8}$ & $\mathbf{1 9 6 7}$ \\
\hline Lucas & $-^{\mathrm{a}}$ & $23,873(19.5)^{\mathrm{b}}$ \\
Ottawa & 7,485 & $8,398(5.9)$ \\
Sandusky & 21,000 & $15,932(6.6)$ \\
Wood & 19,217 & $17,616(4.9)$ \\
\hline Total & & 41,946 \\
\hline
\end{tabular}

${ }^{a}$ The 1958 Lucas County figure was calculated with an incorrect standard (H. G. Smith, Soil Conservation Service, Columbus, Ohio, personal communication); therefore, the totals are for the three-county area with comparable data.

${ }^{b}$ In parentheses percent of county inventoried which was forested.

\section{Accumulation of Data}

A measure of the annual and seasonal effort to conduct this study is of importance. Unfortunately, the person-days spent in the field were not recorded. The number of nest boxes checked during the nesting season provides an index of annual effort during the $30-\mathrm{yr}$ study. This measure is admittedly crude because the number of visits to each nest box was not recorded. For example, some of the boxes could not be visited more than once during several of the years (for additional details see results). Forty-five boxes were checked in 1944, the first year of the study. The average number of nest boxes checked for each 5-yr period during the study was as 
follows: $479,727+, 985+, 730,650,678$. The exact number of nest boxes checked from 1952 to 1955 is unknown; however, a high percentage of the boxes were checked only once at the time young were about to fledge. From 1956 to 1973, the annual effort was consistent. More than 4,249 boxes were checked during the 30 -yr period.

\section{Breeding Season}

Pairs appeared in the nest boxes by the first week of February. During the initial years of the study, some nest desertions resulted from visiting the boxes in February and March. Therefore, in later years the nest boxes were not checked before mid-April. Most screech owls were incubating by mid-April, and, unless the incubating birds were handled, the nests were not deserted. Nest boxes were checked at this time and the males banded if they were in the nest box. Females were not handled until the young hatched. The nest boxes were generally checked three times between midApril and early June. The females were banded during the first check in which young were in the nests. The young were not banded until the color phase could be determined.

\section{Postfledging Period}

Nest boxes were little used after the young fledged, but use began to increase in October when the deciduous trees lost their leaves. We visited nest boxes only rarely in late summer or early fall.

\section{Winter Period}

November, December, and January was a period of much nest box use by individual birds. The wood duck boxes were checked periodically during these months and a large number of screech owls was banded. Beginning in the early 1960's all boxes were visited during the annual maintenance check in January; not all boxes were visited during the winter in the earlier years.

In addition to roosting, the screech owls used the boxes for feeding stations during winter. The trait of carrying prey to a cavity before feeding may have evolved: (1) to lower screech owl vulnerability to predation by larger owls, (2) to prevent other animals from eating the prey not consumed immediately by the owls, (3) as a food storage technique to carry the owls over periods of inclement weather or periods of low food availability, or (4) from the habit of the male feeding the female (Burton 1973). This foodcarrying trait accounts for the large number of prey items recorded in the nest boxes. As mentioned above, the owls did not use the nest boxes in late summer or early fall when the leaves of deciduous trees are present. We believe the dense foliage protected the screech 
owl from predation by larger owls during this period. Thus, the need for using a cavity as a feeding station was minimized in the late summer and early fall.

\section{TAXONOMY}

The screech owl is confined to North America and has a continuous breeding distribution from southeastern Alaska, southern British Columbia, southern Manitoba, southern Ontario, southern Quebec, and Maine south to the Cape district of Baja California, Jalisco, Hidalgo, southern Tamaulipas, and Florida (American Ornithologists' Union 1957). The American Ornithologists' Union also recognizes the whiskered owl (O. trichopsis) in the mountain areas from southeastern Arizona to Honduras and the flammulated owl (O. flammeolus) in southern British Columbia south through the mountains west of the Great Plains to the highlands of Mexico and Guatemala. Additionally, 18 subspecies of the nonmigratory screech owl are recognized.

Numerous other classifications were in effect before 1957 and agreement among taxonomists is still not complete. As with most species of birds, subspecies of the screech owl have been described on the basis of variation in the length of the wing, bill, tail, and tarsus; and in the color pattern of the plumage. In addition to geographical variation, the species is polymorphic in the eastern part of its range and has two distinct color forms: one with the plumage mainly bright rufous and the other with plumage mainly gray. An intermediate color phase also exists, but in low frequency. Elsewhere in the range, only gray birds occur. Owen (1963a) concluded that most of the subspecies had been separated by drawing arbitrary lines through clinal variations. He further indicated that new subspecies were still (in 1959) being described, sometimes based upon as few as five specimens, and thought that the situation should be remedied. Until such time as reproductively isolated sympatric populations are discovered in any part of the range, Owen believed that no subspecies should be recognized and the AOU Check-list entry should include geographical variation.

Marshall (1967), on the other hand, stated that taxonomists have been so engrossed with subspecies that they have ignored a species problem existing in north and middle America. He proposed that seven species and four incipient species of Otus occupy north and middle America, where they overlap without interbreeding, in such combinations as their distributions and habitats permit. Marshall's conclusion were based on both morphology and song patterns. The Committee on Classification and Nomenclature of 
the American Ornithologists' Union has not commented on the screech owl since the 1957 Check-list was published. For the purposes of the present paper, no trinomial is used and the screech owl population is described on the basis of geography, i.e., the nonmigratory population resident in northern Ohio.

\section{FOOD HABITS}

The screech owl is one of the most nocturnal of North American owls. Allen (1924) made a series of observations on the feeding of a brood of young and concluded that the earliest time at which feeding began was 2025 , and the latest was 2112 ; the earliest time at which feeding ceased was 0250 , and the latest was 0415 . He further reported that both parent birds were engaged in caring for the young. These nighttime hunts yielded a variety of food items including many passerine birds that were apparently captured on their roosting sites.

The food habits of most birds of prey were first studied in detail during the latter part of the 19 th and early 20 th centuries. Notable publications of this era were by Fisher (1893) and Errington (1932). In summary, they reported that the screech owl diet consisted of mice, shrews, rats, other mammals, small birds, lizards, amphibians, fish, crayfish, insects, spiders, and other invertebrates. Bent (1938) indicated that although birds do not form as large a portion of the food as mammals, the list of species is a long one. More recently, James and Martin (1950) and Stewart (1969) have added several species of birds to the list.

McDowell and Luttringer (1948) estimated that the diet (percentage occurrence) of the screech owl consisted of $22.75 \%$ mice, $18 \%$ other mammals, $18 \%$ songbirds, with the remaining $41.25 \%$ reptiles, amphibians, fish, and insects, and other invertebrates. An analysis of 419 pellets collected in western Missouri from 1957 to 1967 showed a preponderance of small rodents in screech owl diets (Korschgen and Stuart 1972). Mice and rats together made up $87 \%$ of all foods. Songbirds amounted to $8.4 \%$ in occurrence and only $4.1 \%$ of the volume. Among birds in portions of the southwestern United States and western Mexico, Ross (1969) lists the common screech owl as being both carnivorous and insectivorous, the whiskered screech owl as being primarily insectivorous but on occasion supplementing its diet through carnivorous predation, and the flammulated screech owl, as being entirely insectivorous. Errington (1932) indicated that as a rule screech owls ate what was most convenient to catch and of a size easy to handle. He further noted that their preferred prey seemed to be mice if such were 
available, but in the event of a mouse shortage they readily turned to birds. These studies suggest that the screech owl is an opportunistic predator whose diet includes nearly every class of animal life.

\section{During the Nesting Season}

Allen (1924) intensively studied a pair of nesting screech owls in New York for 45 days and found that birds represented an important portion of the diet. Allen provided a list of $77 \mathrm{birds}$ of 18 species brought to the young during the 45-day period. He concluded that because the feathers in the nest undoubtedly represent many more than one bird of each species, the grand total of birds required to feed the three young owls from the time of hatching until left by the old birds were certainly more than 100 . Recently, Stewart (1969) also indicated that food items found at the nests of screech owls in Ohio and North Carolina consisted primarily of birds. However, Sherman (1911) reported 40 food items during the nesting season (apparently in Iowa), which included 3 frogs, 1 shrew, 28 mice, and only 8 birds.

During our nesting studies, 477 food items were recorded at wood duck nest boxes used by screech owls. Our observations were made between 26 March and 7 June, and nearly all food items found were intact. Most of the food was stored in the nests during the first 2 wk after the young hatched (late April and early May). Fifty-three species of birds were recorded, making up $64.8 \%$ of the items found during the nesting season (Table 2). An attempt was made to calculate biomass of the prey; however, sufficient information was not available regarding the age classes for several of the birds, mammals, and fishes which vary greatly in size. Preliminary calculations suggested that the percentage occurrence and percent biomass in the diet (with the exception of invertebrates which were probably eaten immediately and not adequately represented in the sample) were similar.

Of the five most common species of birds found in the nests, three are transients (Campbell 1968): the yellow-rumped warbler (average arrival 19 April, average departure 20 May), whitethroated sparrow (average arrival 14 April, average departure 22 May), and the ruby-crowned kinglet (average arrival 11 April, average departure $17 \mathrm{May}$ ); one was a permanent resident (the house sparrow); and one was primarily a summer resident (the starling) nesting in northern Ohio in May. Furthermore, 49 of the 53 species of birds found in the diet of the screech owl must be considered migratory. Therefore, the screech owl definitely takes advantage of the spring migration of small birds to feed its young. 
Table 2. Species stored as food by screech owls during the nesting season in northern Ohio $a$.

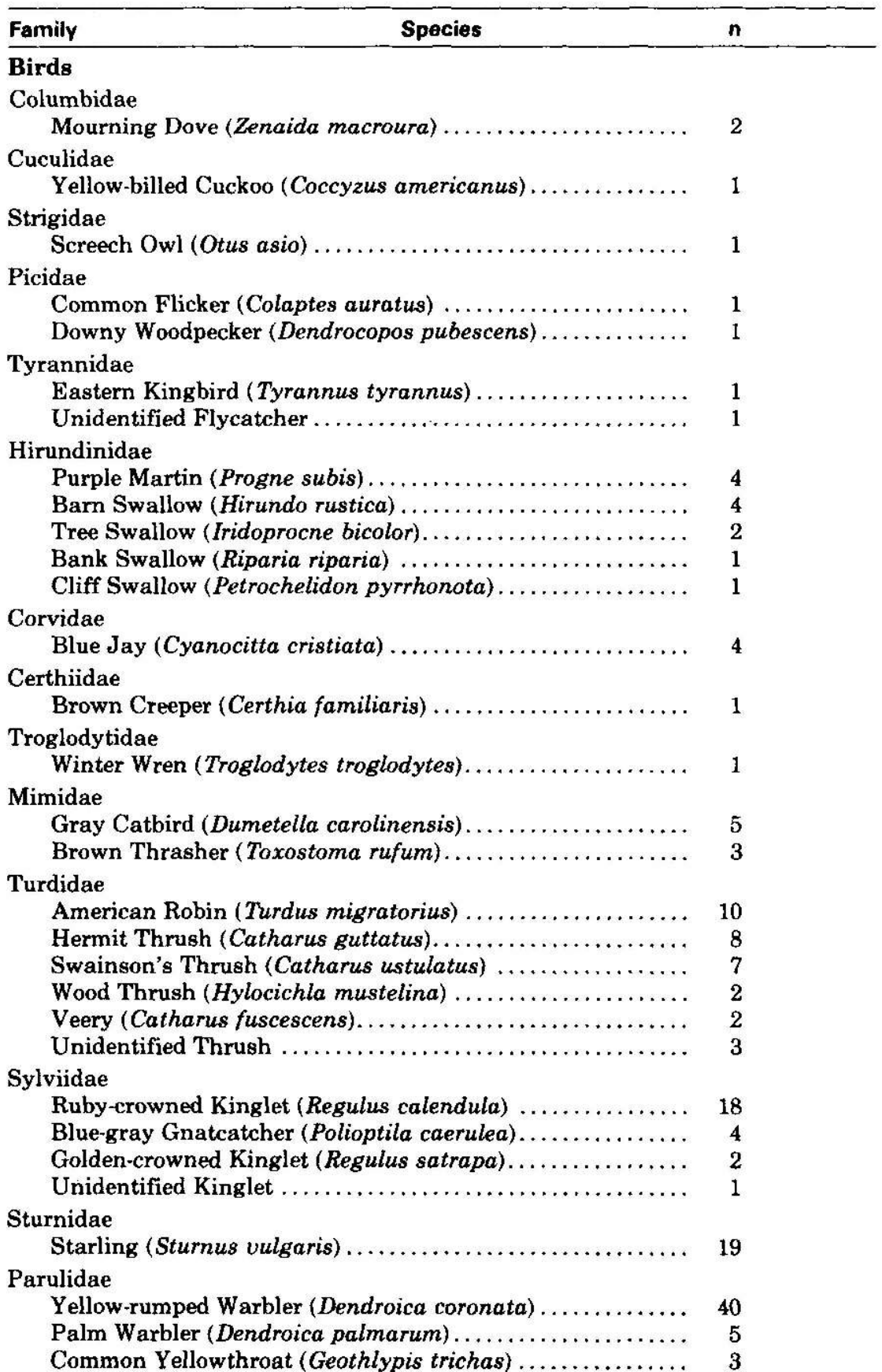


Table 2 (Cont'd)

Cape May Warbler (Dendroica tigrina) ................ $\quad 2$

Black-and-white Warbler (Mniotilta varia) ............. 1

Chestnut-sided Warbler (Dendroica pensylvanica) ........ 1

Tennessee Warbler (Verminvora peregrina) ............. 1

Yellow Warbler (Dendroica petechia) ...................

Nashville Warbler (Vermivora ruficapilla) .............. 1

Canada Warbler (Wilsonia canadensis) ............... 1

Unidentified Warbler.............................. 6

Ploceidae

House Sparrow (Passer domesticus) $\ldots \ldots \ldots \ldots \ldots \ldots \ldots .25$

Icteridae

Red-winged Blackbird (Agelaius phoeniceus)........... 5

Common Grackle (Quiscalus quiscula) ............... 5

Brown-headed Cowbird (Molothrus ater)............. 1

Thraupidae

Scarlet Tanager (Piranga olivacea) $\ldots \ldots \ldots \ldots \ldots \ldots \ldots \ldots, 1$

Fringillidae

White-throated Sparrow (Zonotrichia albicollis) .......... 37

Song Sparrow (Melospiza melodia) ................. 14

Cardinal (Cardinalis cardinalis) .................... $\quad 7$

American Goldfinch (Spinus tristis) ................. 4

Dark-eyed Junco (Junco hyemalis) ................. 4

Rose-breasted Grosbeak (Pheucticus ludovicianus) ....... 3

Chipping Sparrow (Spizella passerina) ............... 2

Field Sparrow (Spizella pusilla) .................... 2

Savannah Sparrow (Passerculus sandwichensis) ......... 2

Tree Sparrow (Spizella arborea) .................... 1

Vesper Sparrow (Pooecetes gramineus) ................ 1

Indigo Bunting (Passerina cyanea) .................. 1

Rufous-sided Towhee (Pipilo erythrophthalmus) ......... 1

Unidentified Sparrow . . . . . . . . . . . . .

Unidentified Family

Small Bird $. . \ldots \ldots \ldots \ldots \ldots \ldots \ldots \ldots \ldots \ldots \ldots \ldots \ldots, 16$

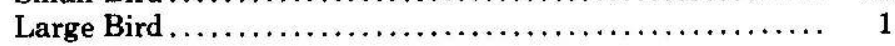

Subtotal (percent occurrence) ................ $309(64.8 \%)$

\section{Mammals}

Soricidae

Unidentified Shrew $\ldots \ldots \ldots \ldots \ldots \ldots \ldots \ldots \ldots \ldots, \quad 4$

Chiroptera (Unknown Family)

Sciuridae

\section{Cricetidae}

Deer Mouse (Peromyscus sp.)..................... 37

Meadow Vole (Microtus sp.) ....................... 52

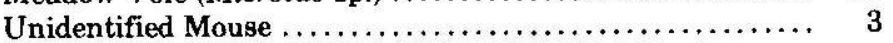

Muridae

Norway Rat [young] (Rattus norvegicus) ............. 6

House Mouse (Mus musculus) ..................... 39 
Table 2 (Cont'd)

Leporidae

Eastern Cottontail [leg] (Sylvilagus floridanus) ......... 1

Subtotal (percent occurrence) ................. 145 (30.4\%)

Amphibians

Ranidae

Leopard Frog (Rana pipiens) .................... 5

Subtotal (percent occurrence) $\ldots \ldots \ldots \ldots \ldots \ldots \ldots \ldots . \quad 5(1.0 \%)$

Fish

Centrarchidae

Green Sunfish (Lepomis cyanellus) ................ 5

Clupeidae

Gizzard shad (Dorosoma cepedianum) $\ldots \ldots \ldots \ldots \ldots \ldots \ldots, 8$

Cyprinidae

Unidentified Minnow $\ldots \ldots \ldots \ldots \ldots \ldots \ldots \ldots \ldots \ldots, \quad 1$

Subtotal (percent occurrence) $\ldots \ldots \ldots \ldots \ldots \ldots \ldots \ldots .14(2.9 \%)$

Invertebrates

Crayfish (Cambarus sp.) ......................... 2

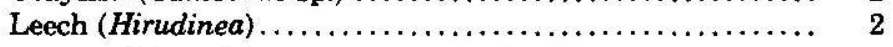

Subtotal (percent occurrence) $\ldots \ldots \ldots \ldots \ldots \ldots \ldots \ldots . \quad 4(0.8 \%)$

Grand Total $. \ldots \ldots \ldots \ldots \ldots \ldots \ldots \ldots \ldots \ldots \ldots \ldots \ldots \ldots \ldots \ldots \ldots \ldots \ldots \ldots \ldots, \quad 477(99.9 \%)$

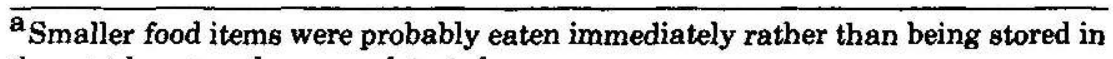
the nest boxes and were undetected.

A nest box containing four young screech owls at the Winous Point Shooting Club had 40 dead birds stored on 5 May 1972. These included 24 yellow-rumped warblers, 3 common yellowthroats, 1 palm warbler, 2 white-throated sparrows, 1 Nashville warbler, 4 blue-gray gnatchatchers, and 5 unidentified birds-2 of which were sparrows but not house sparrows. When the nest was revisited on 22 May 1972 to band the four young, no food was left in the box. Young flightless starlings were also taken from their nests on several occasions. Three young starlings and one adult were found in a nest box on 14 May 1955 . Several trips were apparently made by the screech owl to the starling nest to fill its coffers.

\section{In Autumn and Winter}

Data collected by Wilson (1938) at Ann Arbor, Michigan, primarily in the autumn and winter, showed a preponderance of 
mammals in the screech owl diet. Only four skulls of birds $(0.3 \%$ frequency) were found in 1,408 pellets containing 1,549 skulls. Animals which were identified included: meadow mice (87\%); deer mice (5\%); Cooper lemming mice, Synaptomys cooperii (3\%); shorttailed shrews, Blarina brevicauda (3\%); the remainder $(2 \%)$ included jumping mice, Zapus hudsonius; least shrews, Cryptotis parva; red squirrels, Sciurus hudsonicus; eastern moles, Scalopus aquaticus; Norway rats, birds, parts of crayfish, and insects. Wilson concluded by saying that the screech owl's diet showed a definite cycle. During the spring many owls fed upon insects and amphibians. Elsewhere in his paper Wilson (1938:193) notes, "The tendency for owls in this vicinity to ignore birds can possibly be explained by the abundance of mice . . . ." Similar results were reported from Michigan in a more recent study by Craighead and Craighead (1956) who reported that meadow mice and deer mice made up $95.3 \%$ of the diet in 1942 and $87.2 \%$ in 1948 . The percentage of small birds (1.2 and 11.4\%) showed a substantial increase in the latter winter. According to the Craigheads, this trend toward more small birds in the diet reflected the change in the relation of meadow mice to small bird densities of the latter year.

Fall and winter food items found in the nest boxes during our study totaled 121 . The information was collected between 15 October and 23 February, with the majority being recorded in December. We estimated that the screech owl diet during the fall and winter in northern Ohio consisted of approximately $60.3 \%$ mammals, $26.4 \%$ birds, $5.8 \%$ fish, $5.0 \%$ frogs, and $2.5 \%$ crayfish (Table 3). The nonmigratory house sparrow and cardinal formed over half of the avian food items whereas the migratory bird species were most important during the nesting season.

An observation made in January 1971 was of special note. A screech owl's talons had pierced the skull of a blue jay, but both birds were found dead entangled in a hawthorne tree (Crataegus sp.). A defective eye was noted in 13 owls captured during the study. Generally, the defective eyes were sealed shut. The defective eyes may have resulted from owls trying to capture prey in heavily wooded areas; however, the incidence of eye injuries was low (only 13 in more than 3,000 birds handled). 
Table 3. Food items found at nest boxes occupied by screech owls in the fall and winter in northern Ohio ${ }^{a}$.

\begin{tabular}{|c|c|c|c|}
\hline Birds & Mammals & Fish & $\begin{array}{c}\text { Amphibians and } \\
\text { crayfish }\end{array}$ \\
\hline House sparrow ... 9 & $\begin{array}{l}\text { Meadow } \\
\text { mouse } \ldots .28\end{array}$ & Gizzard shad & Leopard frog. 6 \\
\hline Cardinal ......... & Deer mouse . 20 & Bullhead..... 1 & Crayfish ..... 3 \\
\hline Mourning dove... 4 & House mouse 10 & $\begin{array}{l}\text { Uńidentified } \\
\text { fish } \ldots \ldots \ldots 1\end{array}$ & \\
\hline Blue jay ....... 3 & Norway rat. 9 & & \\
\hline Tree sparrow...... 2 & Shrew ...... 5 & & \\
\hline Starling $\ldots \ldots \ldots \quad 1$ & $\begin{array}{c}\text { Unidentified } \\
\text { mouse } \ldots . . \quad 1\end{array}$ & & \\
\hline Common redpoll . 1 & & & \\
\hline Screech owl ..... 1 & & & \\
\hline Hermit thrush ... 1 & & & \\
\hline American robin $\ldots 1$ & & & \\
\hline Common flicker.. 1 & & & \\
\hline Total items $\ldots \ldots .32$ & $\ldots \ldots \ldots \ldots, 73$ & $\ldots \ldots \ldots \ldots \ldots 7$ & $\ldots \ldots \ldots \ldots, 9$ \\
\hline $\begin{array}{l}\text { Percent } \\
\text { (occurrence).. } 26.4\end{array}$ & $\ldots \ldots \ldots \ldots, 60.3$ & $\ldots \ldots \ldots \ldots .8$ & $\ldots \ldots \ldots \ldots, 7.5$ \\
\hline
\end{tabular}

\section{Fish in the Diet}

During the 1973 nesting season, a nest box on our study area was found with several dozen gizzard shad. Five green sunfish were also noted in a nest on 5 May 1972 and one minnow on 3 May 1973. Several other nest boxes smelled of fish when they were visited, although no fish were present.

The presence of fish in the diet made us curious about 10 band recovery letters of screech owls that were reported to the Bird Banding Laboratory as drowned. It is doubtful that fishing activities by the owls led to their deaths. Six were found in water tanks (specifically, two in horse troughs and one in a windmill tank), two in rain barrels, one in a backyard swimming pool, and no details were given on the remaining recovery. Although it might be suspected that the drowned birds were all young and inexperienced, only three were less than 2 mo old, whereas all of the others were more than $1 \mathrm{yr}$ old. Kelso (1944) has included water as one of the chief considerations in the choice of territory, along with suitable roosting and nesting cavities, and the absence of larger species of 
owls. Kelso indicated that screech owls will drink every day and bathe every 3 or 4 days if water is available. The birds that drowned may have been attempting to bathe or drink, or, more likely, attempting to catch insects or rodents in or near the water. Records of fishing appear in the literature (e.g., Treat 1889), and live fish have been found in tree cavities utilized by screech owls (Frazar 1877).

An incident in our study area on 8 December 1946, provides additional information concerning the relationship of screech owls to water. An oil slick was noticed on the Portage River and three screech owls from the area were captured that day with their legs and underparts covered with oil. The oil on one owl was still present on 14 January 1947 but it had been removed by 27 April 1947. We believe that if the owls were bathing in the water, oil would have been found throughout their plumage. These data lend support to the contention that screech owls take live prey from streams and ponds, and that aquatic food items found in nest boxes were not merely carcasses found along the shoreline. Based on our data, we cannot answer the question, "Do all screech owls take fish occasionally or do a few birds specialize in fish?"

\section{Seasonal Variation}

A seasonal pattern in the food habits of the screech owl became apparent during this study, although our sampling method was biased, i.e., most of the invertebrates taken by the screech owls were probably undetected in our study. Actually, the mammals and birds exchanged places of importance between the nesting season and the fall and winter (Table 4). Furthermore, the important bird species in the diet were nearly all migratory (Table 2) and not available during the other portions of the year.

Table 4. The relative importance of birds to mammals in the seasonal diet of the screech owl (data obtained from nest boxes).

\begin{tabular}{cccc}
$\begin{array}{c}\text { Time } \\
\text { collected }\end{array}$ & $\begin{array}{c}\text { No. } \\
\text { mammals }\end{array}$ & $\begin{array}{c}\text { No. } \\
\text { birds }\end{array}$ & $\begin{array}{c}\text { Percent } \\
\text { birds }\end{array}$ \\
\hline Nesting season $\ldots .$. & 145 & 309 & 68 \\
Fall and winter $\ldots . .$. & 73 & 32 & 30 \\
\hline
\end{tabular}

a The aggregate of birds plus mammals.

Only rarely have authors discussed the food habits of the screech owl during all seasons of the year, although Baird et al. (187:57) stated, "The food is chiefly small quadrupeds, insects, and occasionally, when they have young, small birds." Fisher (1893) presented tabular data on mammals, birds, and other items found 
in the stomachs of birds collected during various months of the year, but did not analyze the data quantitatively for seasonal variation. Fisher (1893:166), however, did state, "It must be said that occasionally it is destructive to small birds, especially during the breeding season, when it has a number of hungry mouths to fill, and also in suburban districts where its favorite food is hard to procure." Fisher's data were collected primarily in the eastern United States. A reanalysis of his bird and mammal data suggested findings similar to ours reported in Table 4.

The $\mathbf{4 7 9}$ food habit cards (approximately one-half of which were used by Fisher [1893]) filed at the Patuxent Wildlife Research Center, Laurel, Maryland, were reanalyzed for seasonal trends in the screech owl diet (Tables 5 and 6). Only data based on stomach contents were considered, and small sample sizes in June, July, August, and September made it necessary to pool 2-mo periods. The relative importance of arthropods in the diet throughout the year was evaluated on the basis of presence or absence in each stomach. This eliminated the problem of tremendous fluctuations in numbers present in individual stomachs and the problem of trying to obtain an exact count of the numbers present. The importance of arthropods (primarily insects) peaked in late summer and declined during the winter (Table 5). It must be emphasized that the arthropods were not detected in our study probably because they were eaten immediately instead of stored. The diet pattern followed availability, again indicating that the screech owl is an opportunistic feeder. The relative importance of birds to mammals, based on the food habit cards (Table 6), was nearly identical to that found in our study (Table 4).

Table 5. The relative importance of arthropods (primarily insects) in the seasonal diet of the screech owl (data obtained from 479 stomach content cards at Patuxent Wildife Research Center).

\begin{tabular}{|c|c|c|c|}
\hline $\begin{array}{c}\text { Month } \\
\text { collected }\end{array}$ & $\begin{array}{l}\text { Stomachs } \\
\text { checked }\end{array}$ & $\begin{array}{c}\text { No. samples with } \\
\text { arthropods }\end{array}$ & $\begin{array}{l}\text { Percent with } \\
\text { arthropods }\end{array}$ \\
\hline January ........... & 56 & 6 & 11 \\
\hline February $\ldots \ldots \ldots \ldots$ & 34 & 9 & 26 \\
\hline March ............ & 38 & 9 & 24 \\
\hline April...$\ldots \ldots \ldots$ & 28 & 16 & 57 \\
\hline May $\ldots \ldots \ldots \ldots \ldots$ & 46 & 34 & 74 \\
\hline June-July . ........ & 40 & 31 & 78 \\
\hline August-September . & 23 & 20 & 87 \\
\hline October ............ & 40 & 24 & 60 \\
\hline November...$\ldots \ldots$ & 98 & 42 & 43 \\
\hline December .......... & 76 & 12 & 16 \\
\hline
\end{tabular}

${ }^{a}$ Only samples collected in the Northeastern United States and Ontario. 
Table 6. The relative importance of birds to mammals in the seasonal diet of the screech owl (data obtained from 479 stomach content cards at Patuxent Wildlife Research Center).

\begin{tabular}{|c|c|c|c|c|}
\hline $\begin{array}{l}\text { Month } \\
\text { collected }\end{array}$ & $\begin{array}{l}\text { Stomachs } \\
\text { checked }\end{array}$ & $\begin{array}{c}\text { No. } \\
\text { mammals }\end{array}$ & $\begin{array}{c}\text { No. } \\
\text { birds }\end{array}$ & $\begin{array}{c}\text { Percent } \\
\text { birds }^{a}\end{array}$ \\
\hline January ................. & 56 & 33 & 15 & 31 \\
\hline February $\ldots \ldots \ldots \ldots \ldots \ldots$ & 34 & 15 & 5 & 25 \\
\hline March $\ldots \ldots \ldots \ldots \ldots \ldots \ldots$ & 38 & 21 & 6 & 25 \\
\hline April $\ldots \ldots \ldots \ldots \ldots \ldots \ldots$ & 28 & 8 & 11 & 58 \\
\hline May $\ldots \ldots \ldots \ldots \ldots \ldots \ldots$ & 46 & 3 & 4 & 57 \\
\hline June-July ............... & 40 & 3 & 6 & 67 \\
\hline August-September . . . . . . . . & 23 & 5 & 4 & 44 \\
\hline October...$\ldots \ldots \ldots \ldots \ldots \ldots$ & 40 & 21 & 8 & 28 \\
\hline November $\ldots \ldots \ldots \ldots \ldots \ldots \ldots$ & 98 & 52 & 17 & 25 \\
\hline December $\ldots \ldots \ldots \ldots \ldots \ldots \ldots$ & 76 & 45 & 14 & 24 \\
\hline
\end{tabular}

$\mathrm{a}_{\text {The aggregate of birds plus mammals. April-September the percentage of birds }}$ was 57 , whereas the percentage for October-March was 26 . Other vertebrates in the stomachs include 7 toads, 7 frogs, 2 lizards, and 3 fish.

The nesting season of the screech owl seems to be timed to take advantage of the spring migration of small birds. Lack (1968) concluded that breeding everywhere is timed in relation to the availability of food for the young. Eleanora's falcon (Falco eleanorae) of the bare rocky islands in the Mediterranean is another species whose nesting season is correlated with the migration of small birds (Vaughan 1961). This falcon, however, has young in September or October and feeds on the small birds migrating south at this season of the year.

The food source for screech owls during the nesting season is possibly unique for owls. The species is not dependent upon a local rodent population, but is primarily dependent upon the spring migration of birds moving into its hunting territory from great distances away. A series of migrant species move through the nesting area on slightly different schedules in May and offers the screech owl a predictable prey source during the complete period when young are in the nest.

\section{MIGRATION AND DISPERSAL}

The 1957 Check-list of the American Ornithologists' Union states that the screech owl in the northeastern United States is mainly resident, but wanders in winter south to Alabama and 
Georgia. Owen (1963a), probably repeating the Check-list, also indicated that a few birds breeding in the North apparently move south in winter. Evidence of such movement between States, based on banding data, is nonexistent. Most interstate recoveries involved 16- to $32-\mathrm{km}$ (10- to $20-\mathrm{mi}$ ) movements of birds banded near the State lines, although two definite exceptions were found. One bird was banded in Minnesota and reported $300 \mathrm{~km}(185 \mathrm{mi})$ southeast in Iowa and another was banded on our study area in northern Ohio and recovered $235 \mathrm{~km}(145 \mathrm{mi})$ northwest in Michigan. Both recoveries were reported during the first year of life from birds banded as nestlings. The first bird was banded on 25 May 1932 and found dead on 20 December 1932, and the latter was banded on 14 May 1957 and found dead on 20 December 1957. Since the two recoveries were in opposite directions, they suggest a dispersal of young rather than migration. Our findings are in agreement with Fisher's (1893:167) statement, "This owl breeds throughout its range, and does not migrate or even wander far during the winter months."

\section{Dispersal Related to Age and Season}

Banding data show that young screech owls begin dispersing from their natal area in late summer and early fall (Table 7), and that by about 1 October, only one-fourth of the surviving young remain in the $10^{\prime}$ block (approximately 23,500 -hectare area ${ }^{1}$ ) where they were hatched. Some young disperse more than $160 \mathrm{~km}(100$ mi). In contrast, about three-fourths of the adult birds remain sedentary and stay in the $10^{\prime}$ block where banded (Table 7). In addition, $87 \%$ of the adults remained within $16 \mathrm{~km}(10 \mathrm{mi})$ of the banding site and no bird moved more than $64 \mathrm{~km}(40 \mathrm{mi})$ (Table 8 ). Furthermore, three of the four birds that moved beyond $32 \mathrm{~km}(20$ mi) were 6 yr old or older; they may have moved the additional distance to obtain a new mate after their original mate died (adult screech owls have a relatively high adult mortality rate). General$\mathrm{ly}$, there is little movement among adult screech owls. Hence, the major means by which a transfer of individuals occurs among populations of the nonmigratory screech owl is dispersal of young birds. The same findings were reported for the nonmigratory song sparrow by Johnston (1956).

${ }^{1}$ An arbitrary geographical division of longitude and latitude used to report bandings of birds and band recoveries. 
Table 7. A comparison of the seasonal movement of young and adult screech owls banded in northern Ohio and in the remainder of the northeastern United States during the nesting season.

\begin{tabular}{|c|c|c|c|c|c|}
\hline \multicolumn{6}{|c|}{ NESTLINGS (Banded April-June) } \\
\hline Recovery & \multicolumn{5}{|c|}{ Time period of recovery $b$} \\
\hline location ${ }^{a}$ & Apr-June & July-Sept & Oet-Dec & Jan-Mar & Later years \\
\hline $0-6$ miles & $15(94 \%)$ & $20(61 \%)$ & $4(24 \%)$ & $2(25 \%)$ & $8(27 \%)$ \\
\hline \multicolumn{6}{|l|}{ More than } \\
\hline 6 miles & $1(6 \%)$ & $13(39 \%)$ & $13(76 \%)$ & $6(75 \%)$ & $22(73 \%)$ \\
\hline Total & 16 & 33 & 17 & 8 & 30 \\
\hline \multicolumn{6}{|c|}{ 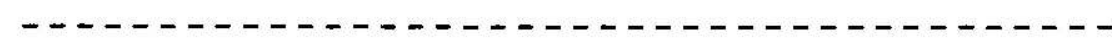 } \\
\hline \multicolumn{6}{|c|}{ ADULTS (Banded March-June) } \\
\hline Recovery & \multicolumn{5}{|c|}{ Time period of recovery $b$} \\
\hline
\end{tabular}

\begin{tabular}{cccccc} 
location a $^{\text {a }}$ & \multicolumn{2}{c}{ Apr-June July-Sept } & Oct-Dec & Jan-Mar & Later years \\
$0-6$ miles & $4(100 \%)$ & $4(80 \%)$ & $4(80 \%)$ & $8(80 \%)$ & $23(74 \%)$ \\
$\begin{array}{c}\text { More than } \\
6 \text { miles }\end{array}$ & $0(0 \%)$ & $1(20 \%)$ & $1(20 \%)$ & $2(20 \%)$ & $8(26 \%)$ \\
$\quad$ Total & 4 & 5 & 5 & 10 & 31
\end{tabular}

a Recoveries within same $10^{\prime}$ block as banded were considered within 6 miles of the banding site. Owls recaptured by banders were not included.

b Months refer to first year after banding.

\section{Dispersal Distance}

The mean distance moved by young birds (calculated after 1 October) was $32 \mathrm{~km}(20 \mathrm{mi})$, although a majority of the birds were reported to have moved much shorter distances (Table 8). Several authors have attempted to determine if dispersal distance is random. Most of the tests have involved a comparison of the observed frequency distribution with the Poisson distribution (French et al. 1968). If the dispersal distance is random, then the number of animals in successive zones outward from the center should show a Poisson distribution. In evaluating this distribution the only data readily available on the place of banding and the place of recovery were the respective $10^{\prime}$ blocks in which these events occurred. To change areas to locations for which distances can be calculated, we used the geographic centers of the $10^{\prime}$ blocks involved. By using this approximation in Table 8, the hypothesis of random dispersal distance for young screech owls was rejected $(P<0.001)$. It appears that two different groups of young birds are 
present in the population a group showing little dispersal (less than $32 \mathrm{~km}$ [20 mi]), and a group wandering considerable distances (100 to $300 \mathrm{~km}$ [ 60 to $185 \mathrm{mi}$ ]). Similar findings were presented for song sparrows by Johnston (1956) and for small mammals by Dice and Howard (1951), Howard (1960), and French et al. (1968). These authors all discussed the possibility that certain individuals within a population may desire to move long distances. Whether there is a genetic basis for his behavior, as proposed by Howard (1960), or whether all individuals are subject to this urge at a certain stage of their lives or season of the year, is uncertain. It should be noted, however, that about $6 \%$ of the screech owls moved beyond the expected range. The percentage is similar to the $10 \%$ reported for song sparrows in Ohio and California (Johnston 1956). Furthermore, Henny and VanVelzen (1972) indicated that approximately $11 \%$ of an osprey (Pandion haliaetus) population disperses from their natal area to breed.

Table 8. Comparison of the observed dispersal distance of nestling screech owls with the Poisson distribution (includes recoveries from 1 October). The adult data are included in parentheses but are not statistically tested as little or no dispersal is indicated.

\begin{tabular}{|c|c|c|c|}
\hline $\begin{array}{c}\text { Category } \\
\text { (miles) }\end{array}$ & $\begin{array}{l}\text { Observed } \\
\text { frequency }\end{array}$ & $\begin{array}{l}\text { Expected } \\
\text { (Poisson) }\end{array}$ & $\mathbf{X}^{2}$ \\
\hline $0-10$ & $25(48)^{a}$ & 4.5 & 93.39 \\
\hline $11-20$ & $21(3)$ & 11.2 & 8.58 \\
\hline $21-30$ & $3(2)$ & 14.0 & 8.64 \\
\hline $31-40$ & $2(2)$ & 11.6 & 7.94 \\
\hline $41-50$ & 07 & 7.27 & \\
\hline $51-60$ & 0 & 3.6 & \\
\hline $61-70$ & 1 & 1.5 & \\
\hline $71-80$ & 0 & 0.5 & \\
\hline $81-90$ & 0 & 0.2 & \\
\hline $91-100$ & 0 & $\mathrm{~T}$ & \\
\hline $101-110$ & 0 & $\mathrm{~T}$ & \\
\hline $111-120$ & $>4$ & 13.0 & 6.23 \\
\hline $121-130$ & 0 & $\mathbf{T}$ & \\
\hline $131-140$ & 0 & $\mathbf{T}$ & \\
\hline $141-150$ & 1 & $\mathrm{~T}$ & \\
\hline $151-160$ & 0 & $\mathbf{T}$ & \\
\hline $161-170$ & 0 & $\mathrm{~T}$ & \\
\hline $171-180$ & 0 & $\mathrm{~T}$ & \\
\hline $181-190$ & 1 & $T$ & \\
\hline Total & 55 & $\overline{54.3}$ & $\overline{124.78}(\mathrm{P}<0.001)$ \\
\hline
\end{tabular}

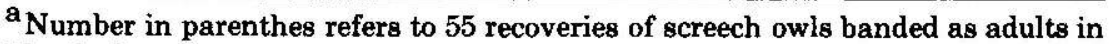
March through June. 
The rigors of wandering during their first autumn and winter probably imposes considerable hardship on the young owls. Many have not yet located suitable roosting areas or other essential requirements, which may make them vulnerable to severe weather and predation from larger owls. However, it should be noted that theoretically, the apparent nonrandom distance of the dispersal has evolved because of its advantage to the species. Current ideas on nonrandom vertebrate dispersal can be conveniently divided into two viewpoints: (1) those that suggest an "inherent" or "genetic" difference between individuals causing them to be shortdistance or long-distance dispersers (e.g., Johnston 1956, Howard 1960 , Lidicker 1962), and (2) those that suggest the only difference between individuals is their ability (relative dominance) to procure a residence (e.g., Murray 1967).

The first group tends to think of innate dispersal in terms of benefiting the population (in spite of the high rate of mortality of long-distance dispersers). The advantages to the population from such behavioral characteristics are said to be: (1) the increase of gene flow to ensure a tendency toward greater panmixia, (2) the increase in ability to spread its range rapidly as favorable habitats are created and to quickly reinvade areas that may have been depopulated by catastrophes, and (3) the increase in ability to regulate population density below carrying capacity. Murray (1967) tends to think in terms of benefit to the individuals, i.e., the dominants that established a nearby residence would be at a distinct advantage. Furthermore, Murray (1967) believes the advantages cited by the first group are actually unselected consequences of selection for individuals that aggressively procure breeding sites but move away from dominant individuals. $\mathrm{He}$ concluded by saying there is no reason to believe that selection has occurred above the level of the individual. Although the mechanisms involved in dispersal are not fully understood, the many advantages of such a trait are readily apparent.

\section{Directional Pattern of Dispersal}

The directional pattern of screech owl dispersal in the northeastern United States was determined by using all birds recovered outside the $10^{\prime}$ block where banded. Retrapped birds are not included here as they would be biased to the study area. As shown in Table 8 , the majority of the birds were reported within 32 $\mathrm{km}(20 \mathrm{mi})$ of the banding site.

The apparent dispersal of more birds east and west is a result of the shape of the $10^{\prime}$ blocks at the latitude where the data were collected (Fig. 5). The blocks are rectangular (approximately $21 \times 11$ 


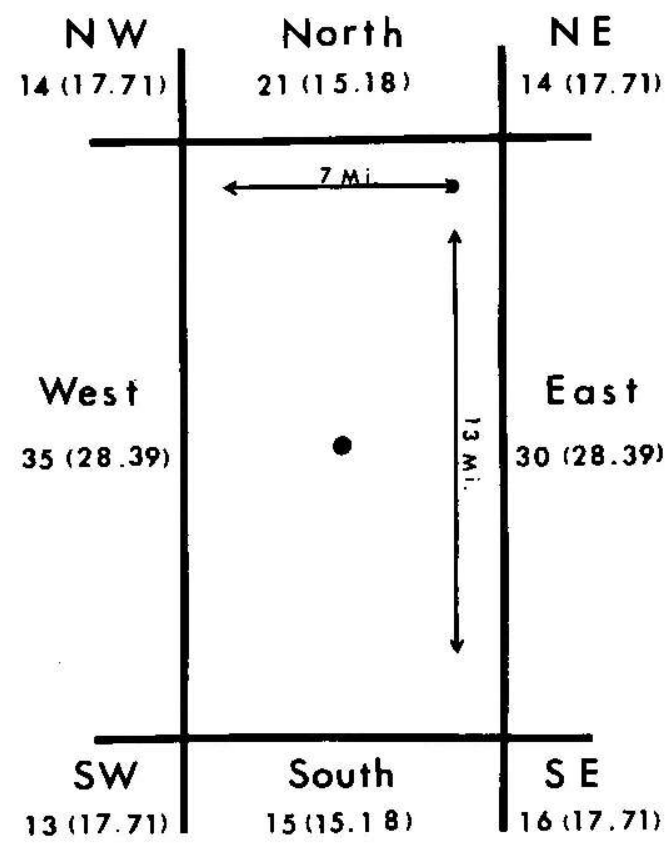

$n=15 B$ RECOVERIES

$X^{2}=6.84,7 d .1$

Fig. 5.-The directional preference of screech owl dispersal in the northeastern United States.

$\mathrm{km}[13 \times 7 \mathrm{mi}])$ and it is a shorter distance (by $53.8 \%$ ) to an adjacent block if one moves east or west. The data in question are frequencies of recovery in eight recovery areas defined with reference to the $10^{\prime}$ block of banding (Fig. 5). Again, we must assume that banding occurred at the center of the block. Because of the shape of the banding block and the recovery areas, these eight frequencies of recoveries would not have equal expected values, even if dispersal were random with respect to the direction of movement. The problem here is to ascertain if the data obtained are consistent with random direction of dispersal.

We computed the distribution of such recovery frequencies conditional on the dispersal distance given a random direction of dispersal. ${ }^{1}$ This computation then allowed a test of the null hypothesis that direction of dispersal is random.

Given the length and width of the $10^{\prime}$ block of banding, and a set of distances for a corresponding set of frequencies, the expected

\footnotetext{
${ }^{1}$ For additional details, see Memorandum in files at Migratory Bird and Habitat Research Laboratory, "Distribution of band recovery frequencies for the screech owl data." dated 20 May 1974.
} 
frequencies can be computed under the hypothesis of random direction of dispersal. The formulae are not complex, except for requiring some inverse cosines. The theoretical frequencies of recovery by area are shown in parentheses in Fig. 5 . The null hypothesis of random directional dispersal is not rejected $\left(X^{2}=6.84\right.$, $7 \mathrm{df}, P=0.50$ ). Therefore, we conclude that the direction of dispersal of the screech owl is random.

\section{Records of Individual Birds}

Multi-recaptures on our study area in northern Ohio provided some additional information on movement or lack of movement in adult birds. Generally, after an adult bird established a nesting site, it was found only at that site in future years. For example, an adult female was brooding five young in a box on 12 May 1952. The bird was also found in the same box in 1954 (brooding five young), in 1957 (brooding three young), and 1959 (brooding four young). The bird was found dead in the immediate vicinity of the nest site on 31 March 1960. Records of this type were very common during the study. One of the longest records for an individual owl was a female that was banded in a box on 19 November 1945 and was retrapped eight times at the same nest box before it was killed by a car on 12 February 1958 (approximate age $13 \mathrm{yr}) 400 \mathrm{~m}(0.25 \mathrm{mi})$ from the nest box. Figure 6 shows a banded screech owl being released at its nest box.

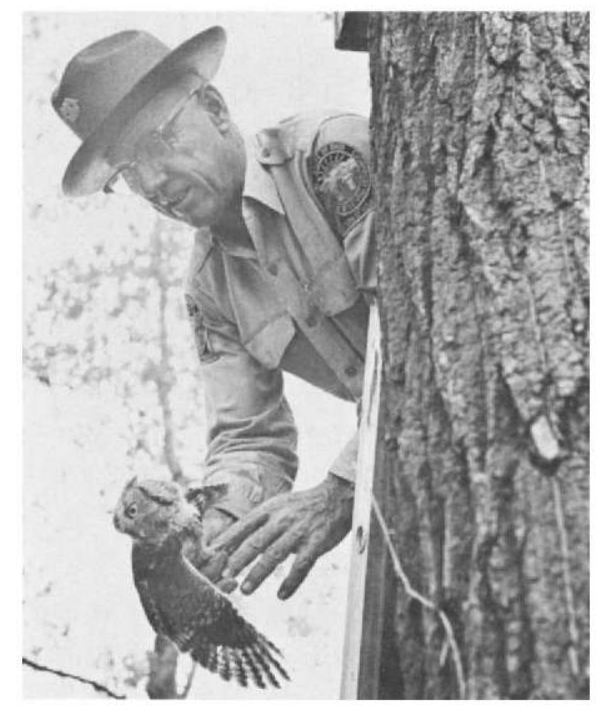

Fig. 6.-A banded screech owl being released at its nest box by the senior author (photo courtesy of George Laycock). 


\section{BREEDING BIOLOGY}

\section{Breeding Season}

Carpenter (1883) discussed the breeding of a pair of screech owls that raised a brood of young in captivity in Massachusetts. He indicated that by 1 February 1883 the actions of the adult birds toward each other began to change and they became more attentive to each other. A clutch of three eggs was found on 15 April and incubation lasted 22 days. Kelso (1944) reported paired owls at Ithaca, New York, by 19 February, but egg-laying did not commence until 15 March. Sherman (1911) reported the first egg of a clutch laid on 27 March 1910 (apparently in Iowa) and that a complete clutch of four eggs was found on 4 April. The first two eggs hatched on 27 April and the remaining two on the next 2 days (26day incubation period). She reported the birds leaving the nest 30 , 31 , and 32 days after hatching. Kelso (1950) reported screech owls in New York leaving the nest in 31 to 35 days. Bent (1938) indicated that the incubation period is variously reported as lasting from 21 to 30 days, but that the average is probably around 26 days as determined by Sherman (1911). Craighead and Craighead (1956) studied 28 nests in Superior Township, Michigan, in 1942 and 1948. They reported that the first selection of territories began in late February. The earliest egg-laying date was 18 April and the earliest hatching date was 12 May. The mean date for the broods leaving the nest was 1 June:

During our study, pairs of owls were first seen together in the nest boxes as early as 1 and 3 February; egg-laying began considerably later. The chronology of the nesting season in northern Ohio may be determined from the data in Table 9. Small young ( 1 to 10 days old) were first seen in the nests during 11-20 April; however, the majority of small young (70\%) were found during 21 April-10 May. Therefore, most of the eggs were hatched from 15 April-5 May. Assuming a 26-day incubation period, egg-laying began about 15 March for the majority of the population with a few laying 5 to 10 days earlier. A few small young were seen as late as the first week in June. These young were probably the results of renesting efforts. Thus, most young in the northern Ohio fledge during the last week of May or the first week of June. The young attain a bandable size with their color readily apparent at about $3 \mathrm{wk}$ of age (10 days before fledging). 
Table 9. Percentages of three size categories of young screech owls in 10-day periods during the brooding season in northern Ohio.

\begin{tabular}{lcccc}
\hline \multicolumn{1}{c}{ Date } & $\begin{array}{c}\text { Small young } \\
(\simeq 1-10 \text { days old })\end{array}$ & $\begin{array}{c}\text { Medium young } \\
(\simeq 11-20 \text { days old }\end{array}$ & $\begin{array}{c}\text { Bandable young } \\
(\simeq 21-30 \text { days old })\end{array}$ \\
\hline $11-20$ April & 6 & 0 & 0 \\
21-30 April & 33 & a & 4 & 5 \\
1-10 May & 37 & 62 & 17 \\
11-20 May & 18 & 28 & 43 \\
21-31 May & 5 & 6 & 30 \\
1-10 June & 2 & 0 & 4 \\
11-20 June & 0 & 0 & 1 \\
\hline Number of nests & & & 440 \\
in sample & 101 & 71 &
\end{tabular}

${ }^{a}$ Longitudinal line refers to peak period for young in each size category, which in turn documents the progression of the breeding season.

\section{Clutch Size}

Bent (1938) indicated that screech owls lay three to seven eggs, but usually four or five, with the average in favor of five. He further indicated that the extremely large or small sets are rare, and the reports of eight or nine seem doubtful. The average clutch in our study was 4.43 (Table 10 ).

Among egg sets from 12 museums in the eastern half of the United States, the largest clutches were found in the north-central part of the region and the smallest in the Southeast (Table 10). This suggests a clinal pattern in which clutch size, in general, increased from east to west and from south to north. One unusual clutch of 10 eggs was found during our study. The bird was incubating on 2 May 1967 and three medium-sized young were found in the nest on 18 May. Two birds probably laid the eggs. We banded seven young in another nest on 7 May 1954. Since this was our only record of seven young in a nest and there were no infertile eggs found, it is probably safe to assume that the clutch size was seven. The record of this nest is not included in the table, however, because it was not visited when eggs were in the nest. Little effort was made to obtain information on clutch size during our study because disturbance during the incubation period seemed to cause nest abandonment. 
Table 10. Clutch sizes of screech owls in northern Ohio compared with egg sets in 12 museums (nearly all museum sets were collected before 1900).

\begin{tabular}{|c|c|c|c|c|c|c|c|c|c|c|}
\hline \multirow[b]{2}{*}{ Location } & \multicolumn{8}{|c|}{ Clutch size } & \multirow[b]{2}{*}{$n$} & \multirow[b]{2}{*}{ Mean } \\
\hline & 1 & 2 & 3 & 4 & 5 & 6 & 7 & 8 & & \\
\hline Northeast $^{\mathrm{a}} \ldots \ldots$ & 0 & 3 & 17 & 36 & 28 & 8 & 0 & 1 & 93 & 4.27 \\
\hline Northern Ohiob ....... & 0 & 1 & 10 & 37 & 35 & 8 & 0 & 0 & 91 & 4.43 \\
\hline Northcentral $^{c} \ldots \ldots \ldots$. & 0 & 0 & 2 & 7 & 6 & 3 & 0 & 0 & 18 & 4.56 \\
\hline Midwest ${ }^{d} \ldots \ldots \ldots \ldots$ & 0 & 1 & 6 & 5 & 3 & 0 & 0 & 0 & 15 & 3.67 \\
\hline \multicolumn{11}{|l|}{ Arkansas-Oklahoma- } \\
\hline Texas................ & 0 & 0 & 7 & 9 & 0 & 0 & 0 & 0 & 16 & 3.56 \\
\hline \multicolumn{11}{|l|}{ Georgia-South } \\
\hline Carolina-Tennessee ... & 0 & 2 & 5 & 3 & 0 & 0 & 0 & 0 & 10 & 3.10 \\
\hline Florida $\ldots \ldots \ldots \ldots \ldots$ & 1 & 13 & 32 & 7 & 4 & 0 & 0 & 0 & 57 & 3.00 \\
\hline $\begin{array}{l}{ }^{a} \text { Massachusetts, Rho } \\
\text { Maryland, and Washing } \\
\text { b Does not include one } \\
\text { c Ohio, Indiana, Illino } \\
\text { d Missouri, Iowa, Kans }\end{array}$ & $\begin{array}{l}\text { de } \\
\text { ton } \\
\text { clu } \\
\text { is, } \\
\text { as }\end{array}$ & lo & & & & In & & & New & Jersey \\
\hline
\end{tabular}

\section{Nesting Success and Fledging Rates}

Craighead and Craighead (1956) provide the only estimate of the number of young fledged per nesting attempt; however, their estimate was based on several assumptions because the information from most nests was incomplete. They concluded that between 2.6 and 3.0 young were fledged per pair of adults in Michigan and Wyoming.

Much of our information from nests was also incomplete. Many of the nests were not visited early, i.e., during the incubation period, and some unsuccessful nests were not detected. The number of active nests in 1944-73 (Table 11) partially reflects the authors' effort rather than abundance. From these 440 successful nestings, 1,673 young were believed to have been fledged ( 3.80 young per successful nesting). The annual variation in numbers fledged per successful nesting was small (coefficient of variation $[\times 100]$ of 8.2 ). 
Table 11. Success of screech owl nests in northern Ohio, 1944-73.

\begin{tabular}{|c|c|c|c|c|c|}
\hline Year & $\begin{array}{c}\text { No. active } \\
\text { nests }\end{array}$ & $\begin{array}{c}\text { No. nests } \\
\text { successful }\end{array}$ & $\begin{array}{c}\text { Percent } \\
\text { of nests } \\
\text { successfulb }\end{array}$ & $\begin{array}{c}\text { No. young } \\
\text { fledged }\end{array}$ & $\begin{array}{c}\text { Young } \\
\text { fledged per } \\
\text { successful } \\
\text { nest }\end{array}$ \\
\hline 1944 & 4 & 4 & 100.0 & 17 & 4.25 \\
\hline $1945^{\mathrm{c}}$ & 5 & 4 & 80.0 & 16 & 4.00 \\
\hline $1946^{\mathrm{c}}$ & 9 & 6 & 66.7 & 22 & 3.67 \\
\hline $1947^{\mathrm{c}}$ & 19 & 14 & 73.7 & 56 & 4.00 \\
\hline $1948^{c}$ & 20 & 11 & 55.0 & 37 & 3.36 \\
\hline $1949^{\mathrm{c}}$ & 19 & 15 & 78.9 & 61 & 4.07 \\
\hline 1950 & 26 & 24 & 92.3 & 87 & 3.63 \\
\hline 1951 & 11 & 10 & 90.9 & 39 & 3.90 \\
\hline 1952 & 25 & 23 & 92.0 & 85 & 3.70 \\
\hline 1953 & 34 & 31 & 91.2 & 116 & 3.74 \\
\hline 1954 & 49 & 44 & 89.8 & 197 & 4.48 \\
\hline 1955 & 42 & 42 & 100.0 & 161 & 3.83 \\
\hline 1956 & 22 & 20 & 90.9 & 81 & 4.05 \\
\hline 1957 & 16 & 14 & 87.5 & 54 & 3.86 \\
\hline 1958 & 17 & 14 & 82.4 & 50 & 3.57 \\
\hline 1959 & 15 & 12 & 80.0 & 49 & 4.08 \\
\hline $1960^{c}$ & 17 & 11 & 64.7 & 40 & 3.64 \\
\hline $1961^{\mathrm{c}}$ & 12 & 9 & 75.0 & 32 & 3.56 \\
\hline 1962 & 20 & 18 & 90.0 & 70 & 3.89 \\
\hline $1963^{c}$ & 16 & 11 & 68.8 & 40 & 3.64 \\
\hline 1964 & 9 & 9 & 100.0 & 34 & 3.78 \\
\hline 1965 & 8 & 7 & 87.5 & 29 & 4.14 \\
\hline 1966 & 9 & 9 & 100.0 & 30 & 3.33 \\
\hline $1967^{\mathrm{c}}$ & 18 & 16 & 88.9 & 54 & 3.38 \\
\hline 1968 & 13 & 13 & 100.0 & 49 & 3.77 \\
\hline $1969^{c}$ & 12 & 10 & 83.3 & 35 & 3.50 \\
\hline 1970 & 13 & 12 & 92.3 & 45 & 3.75 \\
\hline $1971^{\mathrm{C}}$ & 13 & 11 & 84.6 & 34 & 3.09 \\
\hline 1972 & 18 & 16 & 88.9 & 53 & 3.31 \\
\hline $1973^{d}$ & - & - & - & - & - \\
\hline Total & 511 & 440 & 86.1 & 1,673 & 3.80 \\
\hline
\end{tabular}

a Fledged at least one young.

bThis percentage is biased high because many nests were visited only once when the young attained bandable size.

c Years when 75 percent of nests were visited on two or more occasions.

dData excluded because one egg from each clutch was collected for pesticide study. 
The banding date disclosed variation in the number of young reported per successful nesting (Table 12). The earliest nesting attempts produced slightly more young than later attempts. This may be partially due to the older, more experienced birds nesting first, whereas the late nests may include more first-year breeders. Also, a few renests with small clutch sizes may have been included in the last category. A brood of five young is shown in Fig. 7.

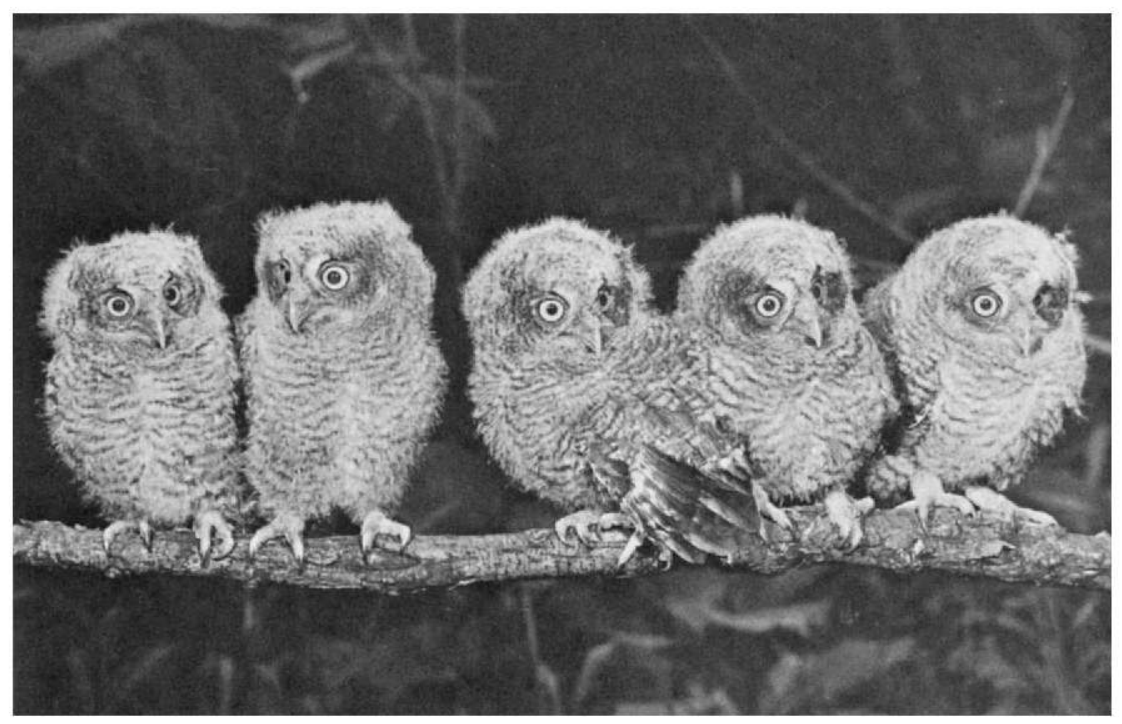

Fig. 7.-Five downy screech owls (photo courtesy of G. Ronald Austing).

Table 12. Number of young screech owls per successful nest during five banding periods (from early to late nesters) in northern Ohio.

\begin{tabular}{lccc}
\hline \multicolumn{1}{c}{ Banding date } & successful & $\begin{array}{c}\text { Number } \\
\text { nests }\end{array}$ & $\begin{array}{c}\text { Mean } \\
\text { per nest }\end{array}$ \\
\hline 22 April - 9 May & 88 & 367 & 4.17 \\
10 May - 15 May & 88 & 336 & 3.82 \\
16 May - 19 May & 88 & 335 & 3.81 \\
20 May - 23 May & 88 & 334 & 3.80 \\
24 May - 20 June & 88 & 301 & 3.42 \\
\hline Total & 440 & 1,673 & 3.80 \\
\hline
\end{tabular}

$a_{\text {The banding dates were adjusted so that an equal number of successful nests }}$ were reported in each banding period. 
Because the data presented in Table 11 include a number of nests that were visited only once, i.e., at the time of banding, a rationale was needed to obtain an estimate of the number of young fledged per breeding pair. The data are obviously an overestimate of the percentage of nesting attempts that were successful. Two methods were used to estimate the number of young fledged per breeding pair: (1) use of only nests with the most complete set of observations, i.e., nests visited initially during incubation, and (2) the Mayfield (1961) Exposure-day Method (and the data which met his criteria).

\section{Nests Visited Initially During Incubation}

This method was restrictive and reduced the number of usable nesting records from the total of 511 to 165 , which were the most complete ones (Table 13). Because egg-laying in northern Ohio begins about 15 March for most of the population, the nests visited between $18 \mathrm{March}$ and $10 \mathrm{April}$ best represent the fledging rate per nesting attempt (Table 13). The fledging rate estimates for 11-30 April were believed to be inflated because of undetected losses before the first visit to the nest. Thus, we believe the best estimate by this rationale is 2.55 young fledged per pair.

Table 13. Screech owl nesting success and fledging rates as related to the date the nest was first visited. Only nests with eggs present at first visit were included.

\begin{tabular}{cccc}
\hline Date first visited & No. of & $\begin{array}{c}\text { No. of young } \\
\text { fledged }\end{array}$ & $\begin{array}{c}\text { Young fledged } \\
\text { per nesting } \\
\text { attempt }\end{array}$ \\
\hline 18 March -10 April & 20 & 51 & 2.55 \\
11 April -20 April & 64 & 178 & 2.78 \\
21 April -30 April & 81 & 238 & 2.94 \\
\hline
\end{tabular}

${ }^{\text {a }}$ All years combined.

\section{Mayfield Exposure-day Method}

Other field workers have often been faced with interpreting nesting success with data from nests that were not observed from the start of incubation. Further, the sample may include some nests for which success of nesting was unknown. If such partially complete records are included (or excluded) from his calculations, there is a danger of distorting the conclusions. Mayfield (1961) presented a way of dealing with this problem by reducing the data to units of exposure, which reflects not only the number of nests but also the length of time each was under observation. A convenient measure of exposure is the nest-day (equivalent to one nest for 1 
day). With this method, all single or multiple observations of individual nests can be incorporated into the sample, even though some of these do not go back to the very beginning or do not carry through to the end. Mayfield (1961) points out that after mortality and survival rates are expressed per nest-day, the probability of survival of eggs and young may be calculated for all or any part of this nesting period. If the survival rate per nest-day is $S$, the probability of survival of a nest for d days is $S^{d}$. Mayfield further pointed out that the survival rate during incubation is different from the rate during the nestling period, so these two stages must be treated separately. Also, egg survival must be considered separately from nest survival because of the loss of individual eggs, particularly at hatching time. The probabilities of survival in different stages of nesting may be combined through the mathematical principle that the probability of a succession of events is the product of their separate probabilities.

We found that only 13 young from successful nestings (nests from which at least 1 young is fledged) were lost in 1,090 exposure days between 1944 and 1973 (loss per exposure-day of 0.012 ). Furthermore, the loss of young per exposure-day was quite consistent throughout the brood rearing period in successful nestings (i.e., 22 April-9 May-0.010, 10-20 May-0.012, and 21 May-20 June-0.015). Based on a 30-day period for the young in the nest, an estimated 0.36 young was lost per successful nesting from the period of hatching to fledging. Thus, we worked backwards from the number of young fledged per successful nesting ( 3.80 from Table 11) to determine the number of young hatched per successful nest. This approach was a necessity because of our weak data for early in the incubation period. Early visits had the potential to cause nest abandonment and thus, it was not possible to estimate egg loss on an exposure-day basis. Egg loss in successful nests was estimated by difference. With an estimated 3.80 young fledged per successful nesting, we estimate that approximately 4.16 young hatched per successful nesting from the 4.43 eggs laid (Table 10). Thus, by difference, an estimated $94 \%$ of the eggs in successful nests hatched. The loss of young after hatching from broods that were not completely destroyed appeared to be low.

As mentioned earlier, the percentage of successful nesting was overestimated in Table 11, particularly during years when less than $75 \%$ of the nests were visited two or more times (Table 11, footnote c). It is most important to obtain an estimate of the percentage of nestings that were successful. Mayfield's (1961) method is again believed applicable. Since few nests were visited more than twice, a problem exists regarding the timing of nest loss. 
Therefore, we must of necessity assume that the loss rate of complete nests was constant through time. This assumption may or may not be true; therefore, our recruitment estimates based on this rationale must be regarded as tentative. Our pooled data indicate that during 5,189 exposure days, 34 nests were lost or believed lost (young in 2 nests may have fledged before being revisited; however, we assumed that one nest was successful). An estimated 0.006552 nest was lost per nest-day. With an incubation period of 26 days and a nestling period of 30 days, each nest was susceptible to loss for 56 days. By applying Mayfield's formula, $\left(0.993448^{56}\right)$ we estimated that $69.2 \%$ of the screech owl nesting attempts in northern Ohio were successful during the study. With 3.80 young fledged per successful nest, an estimated 2.63 young were fledged per nesting attempt based on the Mayfield Exposureday Approach. This estimate is in close agreement with that of 2.55 fledged young based on a much smaller sample of nests observed throughout the breeding season. In summarizing our data on recruitment, we believe that the best estimate of the number of young fledged in northern Ohio during the 30-yr study was about 2.5 to 2.6 young per nesting attempt.

\section{Causes of Nest Loss}

Sixty-six unsuccessful nests were found during our study. The actual cause of nest failure was determined for a few of the nests listed in Table 14. Most of the nests (41) were either deserted or destroyed. Raccoons (Procyon lotor) were implicated in the loss of 15 nests, and the eggs failed to hatch in 7 nests. Craighead and Craighead (1956) noted that fox squirrels (Sciurus niger) destroyed the eggs of two pairs of screech owls in Michigan and appropriated the nest hollows. They also pointed out that screech owl nests and ranges are commonly within the nesting range of the great horned owl (Bubo virginianus) and that young suffer their heaviest mortality soon after leaving the protection of the nest hollow.

Table 14. Causes for screech owl nests being unsuccessful in northern Ohio, 1944-72.

\begin{tabular}{lc}
\hline \multicolumn{1}{c}{ Cause of loss } & Number of nests \\
\hline Deserted or destroyed (reason unknown) & 41 \\
Raccoon predation & 15 \\
Eggs failed to hatch & 7 \\
Young dead in nest & 2 \\
People (children) took young & 1 \\
\hline Total & 66 \\
\hline
\end{tabular}




\section{POPULATION DYNAMICS}

\section{Sex Ratio in Population}

Behavioral differences between sexes are to be expected in most species. Bellrose et al. (1961) described biases involved in sampling waterfowl populations to obtain sex ratios. For waterfowl and many other groups of birds, a bias may result from (1) a differential migration of the sexes (time of year sample collected), (2) the type of area where collection was made (characteristics of the habitat), or (3) a differential vulnerability of the sexes to the method of collection (e.g., shot, trapped, etc.).

The information on screech owls concerning sex ratios may also be biased, although the nonmigratory characteristic of the species tends to minimize several potential biases. The sex data were obtained from the stomach content records filed at the Patuxent Wildlife Research Center. Not all records contained information on sex. To eliminate one potential bias, the information from March through June (the nesting season when the female was probably on the nest) was eliminated from the sample. Thus, for July to February, of 234 screech owls collected in the northeastern United States, $113(48.3 \%)$ were males and $121(51.7 \%)$ were females. The sample did not deviate significantly from the expected 50:50 sex ratio (chi-square $=0.13,1 \mathrm{df}$ ).

Data obtained in our study area could not be analyzed for sex ratio information because of the potential bias associated with the sampling scheme (nearly all birds captured at nest boxes were paired).

\section{Mortality Rates}

Mortality rates for the screech owl have not been estimated previously. In this study, life tables were made from band recovery data in northeastern United States and Ontario; a large percentage of the data came from our study area. Recoveries were not included if information was insufficient to tell if the bird was dead or alive and released. Also, all retrapped birds, sight records, and skeletal remains were omitted. Nestlings were generally banded about 10 days before fledging and, therefore, recoveries during the first 10 days after banding were not included. An initial date (the date after which recoveries would be used in the life tables) of the first 15May after banding was used for the adults, as opposed to 1 January, because we believe that the nonmigratory screech owl does not attain an adult mortality schedule by 1 January. Henny (1972) indicated that most migratory passerines achieve a schedule of 
adult mortality by the first 1 January after hatching; however, the more sedentary species (e.g., cardinal, black-capped chickadee [Parus atricapillus] blue jay) in the northern portion of the United States do not attain their schedule of adult mortality rates until later. This phenomenon was first reported for the sedentary California quail (Lophortyx californicus) by Emlen (1940).

Nestlings and adults banded through 1964 and recoveries processed through August 1974 were included in the analysis. It is believed that the life span of the banded cohort was nearly completed by 1974 as only two recoveries greater than $9 \mathrm{yr}$ of age have been reported during the last $50 \mathrm{yr}$. However, the possibility still exists that the mortality rate estimates from the composite dynamic life table (Hickey 1952) may be biased slightly on the high side.

Mortality rate estimates shown in Table 15 suggest that approximately 32.8 to $39.0 \%$ of the adult population dies annually. The range in the estimates of adult mortality rate is undoubtedly due to small sample sizes, particularly for the cohort banded as nestlings. Probably the best estimate of adult mortality rate would be based on the pooled recoveries from bandings of both nestlings (second year and later) and adults. The combined data yielded an annual adult mortality rate estimate of $33.9 \%$. The first-year mortality rate for young birds is much higher, about $69.5 \%$.

Table 15. Estimates of mortality rates for screech owls banded as nestlings and adults in the northeastern United States and Ontario during 1915-64.

\begin{tabular}{cccccccc}
\hline \multirow{2}{*}{$\begin{array}{c}\text { Age } \\
\text { interval } \\
\text { years }\end{array}$} & \begin{tabular}{c} 
Adults \\
\cline { 2 - 7 } \\
\cline { 2 - 7 } \\
recoveries
\end{tabular} & $\begin{array}{c}\text { Alive at } \\
\text { beginning }\end{array}$ & $\begin{array}{c}\text { Mortality } \\
\text { rate }\end{array}$ & $\begin{array}{c}\text { Number of } \\
\text { recoveries }\end{array}$ & $\begin{array}{c}\text { Alive at } \\
\text { beginning }\end{array}$ & $\begin{array}{c}\text { Mortality } \\
\text { rate }\end{array}$ \\
\hline $0-1$ & 55 & 134 & $0.328^{\mathrm{b}}$ & 73 & 105 & $0.695^{\mathrm{c}}$ \\
$1-2$ & 25 & 79 & & 13 & 32 & $0.390^{\mathrm{b}}$ \\
$2-3$ & 13 & 54 & & 7 & 19 & \\
$3-4$ & 9 & 41 & & 4 & 12 & \\
$4-5$ & 7 & 32 & & 2 & 8 & \\
$5-6$ & 8 & 25 & & 2 & 6 & \\
$6-7$ & 6 & 17 & & 3 & 4 & \\
$7-8$ & 3 & 11 & & 1 & 1 & \\
$8-9$ & 5 & 8 & & 0 & 0 & \\
$9-10$ & 1 & 3 & 0 & 0 & \\
$10-11$ & 1 & 2 & 0 & 0 & \\
$11-12$ & 0 & 1 & & 0 & 0 \\
$12-13$ & 1 & 1 & & 0 & 0 \\
\hline
\end{tabular}

${ }^{a}$ An initial date of the first 15 May after banding was used for all birds not banded as nestlings. On this date, the birds were arbitrarily classified as adults.

${ }^{b}$ Annual adult mortality rate estimate.

$c^{c}$ First-year mortality rate estimate. 


\section{Causes of Postfledging Mortality}

Band recoveries provide some information on causes of mortality, although dead owls found by humans are not a random sample of the mortality occurring in a population. For example, predation by other raptors would most likely be undetected because the carcasses would disappear before being found. Actually, most bands reported to the Bird Banding Laboratory are from birds that died as a result of man's activities (his vehicles, pets, etc.). Furthermore, the majority of the bands are reported as found on dead birds with no cause of death mentioned.

Screech owls hit by motor vehicles and found along roads appear frequently in the sample reported to the Bird Banding Laboratory (Table 16). Sutton (1927) reported 113 requests for permits to retain specimens of the screech owls which had been found dead or in weakened or wounded condition in Pennsylvania. The causes of death included 6 which may have died of starvation or illness, 2 which had flown into window panes, 7 which were caught by steel traps, 1 which had been killed by the felling of a tree, 13 which had been shot, 2 which were alive but in poor condition, and 82 which evidently were killed by flying into automobiles. Schorger (1954) recorded 235 road-killed screech owls during a period of $18 \mathrm{yr}$ between Madison, Wisconsin, and Freeport, Illinois; Stupka (1953) examined 41 screech owls along the highways in or near Great Smoky Mountains National Park. Both Sutton (1927) and Stupka (1953) believed that in most instances these birds were struck and killed while feeding upon prey, primarily insects, along highways.

The recovery data submitted to the Bird Banding Laboratory, as anticipated, suggested that predation on the screech owl by other raptors was of minor importance. Craighead and Craighead (1956), however, indicated that the screech owl was fairly vulnerable to the great horned owl because both often hunt the same habitat.

The importance of the various mortality factors affecting a screech owl population cannot now or perhaps ever be determined. However, it is important to recognize that man, his machinery, his vehicles, his pets, and his buildings and other structures do take their toll; at the same time, it should be understood that many of man's alterations of the habitat have benefited the screech owl. Numerous authors have stated that screech owls seem to take kindly to man's occupation of the land and breed and thrive in the vicinity of his dwellings, in spite of the injudicious warfare which is sometimes waged against them. 


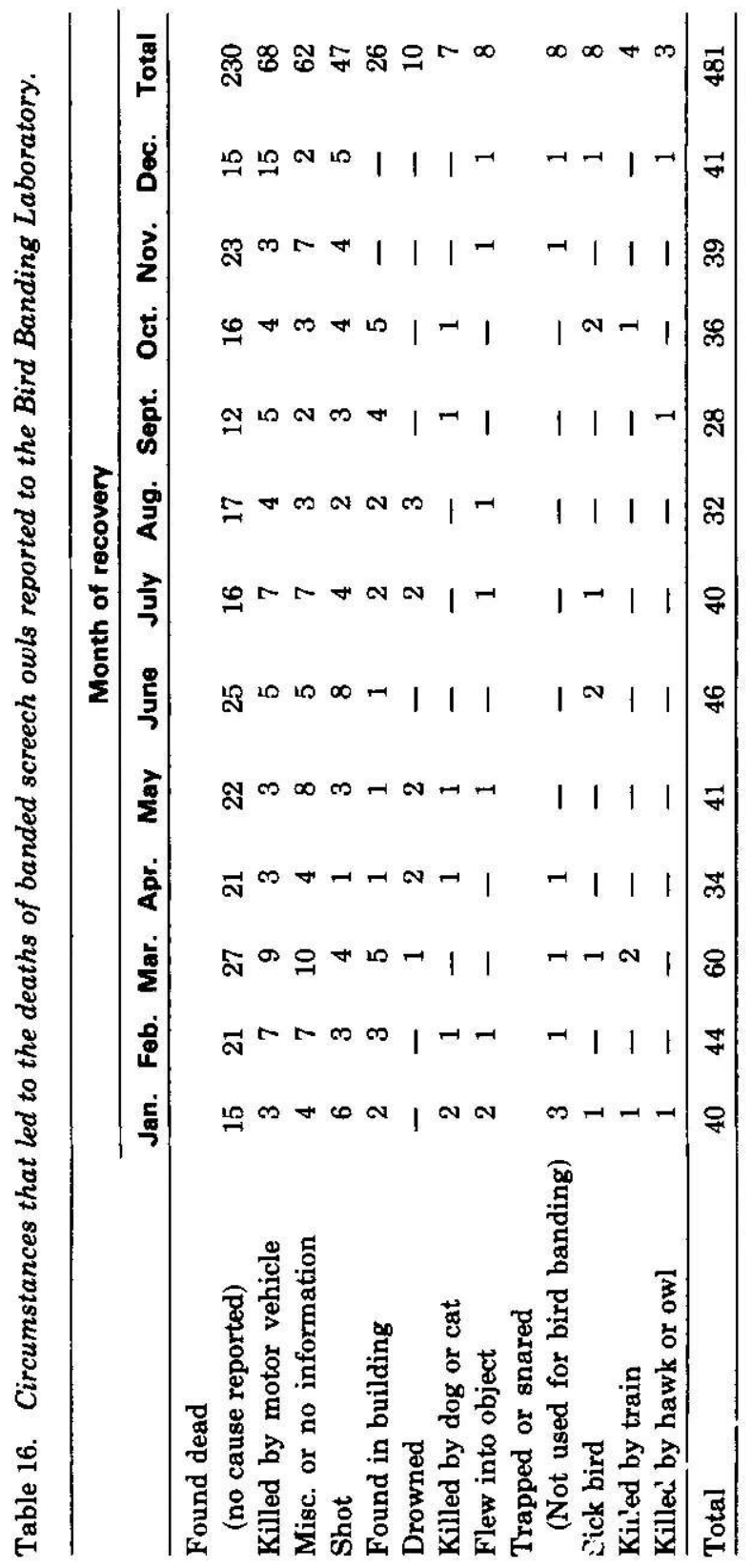




\section{Age at Sexual Maturity}

The age at sexual maturity is one of the most important and difficult parameters to determine for a wild population of birds, and published information on the subject for the screech owl was not available. Screech owls were recorded breeding as 1-yr-olds on 10 occasions ( 7 females and 3 males) during our study, and 3 other 1yr-olds were found in nest boxes in April but with no sign of eggs or a mate. These birds were all banded as nestlings and found the following spring. Of particular interest was a 1-yr-old male that mated with its mother in 1971 and produced one young. Nestings where a 1-yr-old was involved fledged 3.55 young per successful attempt (slightly lower than the 3.80 average for the population, Table 11). Ten is a small number to have of definite records of 1-yrolds breeding considering the amount of time spent in the field during the 30-yr study; however, it must be remembered that the young disperse during the late summer and early fall (Table 7). Thus, the chance of recapturing a banded 1-yr-old screech owl in another nest box is remote.

As well as establishing the capability of 1 -yr-olds to breed, we need to know the percentage that do breed at this age. Of $131-\mathrm{yr}-$ olds found during the nesting season, $10(77 \%)$ were nesting. This estimate may be biased because other nonbreeding 1-yr-olds may not associate with nest boxes and therefore be undetected. Another approach is to compare the number of breeding 2-yr-olds found nesting during the study with the number of 1-yr-olds found nesting. Then, given the average annual adult mortality rate of approximately $33.9 \%$ (from previous section), and given that eight 2-yr-olds were found nesting, we estimated that there should be a total of 12.1 breeding 1-yr-olds located if all 1-yr-olds and 2-yr-olds attempted to nest. Of course, only 10 were found, which provides an estimate of $83 \%(10 / 12.1)$ of the 1-yr-olds attempting to nest annually.

Conclusions regarding the percentage of the 1-yr-old screech owls that attempt to nest annually must be regarded as tentative at this time. Furthermore, the percentage may fluctuate from year to year. Our two estimates (based on very small sample sizes) suggest that an average of possibly 77 to $83 \%$ of the 1-yr-olds attempt to nest annually, but the percentage may be lower.

In comparison, Henny (1972) summarized information from several published and unpublished sources on age at sexual maturity of great horned owls. He concluded that most individuals do not breed until they are 2-yr-olds, although an average of about one-fourth of the population nests as 1-yr-olds, with the percentage 
varying from year to year depending upon local conditions. Similar but more dramatic findings have been reported for other owls that are primarily dependent upon one food source. Barn owls (Tyto $a l b a$ ) were reported to nest at the end of their first year of life (Schneider 1937, Stewart 1952); however, in general, barn owls seem to breed irregularly. Wallace (1963:209) stated, "The barn owl may breed almost continuously during peak years in the Microtus (meadow mouse) cycle, but slow down or skip a breeding season when its staple prey is scarce." Similar observations were recorded for the tawny owl (Strix aluco) in England. Lack (1966) reported that $59 \%$ of the population was breeding pairs, but the percentage that nested in specific years ranged from 0 to $90 \%$. Increases in clutch size also were reported for some species of owls in years when rodents were abundant. Lack (1968) reported that the short-eared owl (Asio flammeus) may lay nine eggs during a vole plague, but only about half that many during other years.

The number of young fledged per successful screech owl pair was very consistent from year to year (Table 11). This is probably the result of the species being an opportunistic feeder. We do not believe that large numbers of breeding-age screech owls fail to produce in years when the local rodent cycle is low, although rodent cycles may have some influence on 1-yr-olds. Unlike the barn owl, tawny owl, and short-eared owl, the screech owl is not totally dependent upon local rodents (or one genus of mouse) for its food supply. In fact, the young are fed a diet which consists largely of small birds of many species which migrate through the area (Table 2). Thus, the varied food supply for the young is not produced locally; it is highly dependable and actually migrates to the owl's hunting areas annually from numerous places, some being considerable distances away. The opportunistic feeding habits of the screech owl apparently tend to maintain a very uniform reproduction annually and, to our knowledge, nonbreeding is limited to a small percentage of the 1-yr-olds. We must caution, however, that more research is needed on sexual maturity.

\section{PESTICIDES AND POLLUTION}

Eggshell thinning has been found to occur widely and is well documented, especially in the United States and England. In the United States, natural populations of at least 22 species representing seven orders have been affected. In seven of eight species where shell thinning exceeded $20 \%$, there was an associated population decline (Anderson and Hickey 1972). The thinning 
began to occur in the United States and England in the mid-forties at the time DDT and other organochlorine insecticides were first available for widespread use (Ratcliffe 1967, Hickey and Anderson 1968). The possible relationship of shell thinning to the use of DDT led to a series of studies to test the effects of DDT and its metabolites on shell thinning and reproduction of birds.

Initial laboratory studies were conducted on mallards (Anas platyrhynchos), black ducks (Anas rubripes), and American kestrels (Falco sparverisu) and showed a direct causal relationship between DDE and eggshell thinning (Heath et al. 1969; Longcore et al. 1971; Wiemeyer and Porter 1970). The next species to be studied in a similar manner was the screech owl (McLane and Hall 1972). The owls were given a dietary dosage of $2.8 \mathrm{ppm}$ of DDE (equivalent to $10 \mathrm{ppm}$ dry weight). Birds fed untreated food in 1970 and DDE dosage in 1971 laid eggs with shells that were $12 \%$ thinner than in 1970. McLane and Hall (1972) concluded that screech owls seem to show greater shell thinning than American kestrels which showed $10 \%$ thinning on a similar diet (Wiemeyer and Porter 1970).

\section{Eggshell Thinning}

The work by McLane and Hall (1972) indicated that screech owls were susceptible to the eggshell thinning phenomenon. In cooperation with the Patuxent Wildlife Research Center, one egg was collected from each of the 21 clutches on our study area in 1973. The eggs were measured for eggshell thickness and analyzed for chlorinated hydrocarbon residues. The remainder of the clutch was observed for hatchability and fledging rates. Klaas and Swineford (In preparation, Patuxent Wildlife Research Center) compared shell thickness in these 1973 eggs with shell thickness in eggs collected before 1947 in Ohio (Table 17). No significant decrease in eggshell thickness in the 1973 population was detected.

Eggshells collected from the field in 1973 were about $8 \%$ thicker than the controls in the laboratory experiment(Table 17). This is of interest because many of the owls in the laboratory experiment were obtained from our study area in northern Ohio in 1967. The reason for the thinner control eggs in the laboratory study is unknown, but it may be due to a number of factors (e.g., age of birds, diet, etc.). 
Table 17. Shell thickness of screech owl eggs.

\begin{tabular}{|c|c|c|c|c|c|}
\hline \multirow[b]{2}{*}{ Location } & \multirow{2}{*}{$\begin{array}{c}\text { No. of } \\
\text { females }\end{array}$} & \multirow{2}{*}{$\begin{array}{l}\text { No. of } \\
\text { eggshells. } \\
\text { measured }\end{array}$} & \multicolumn{3}{|c|}{ Shell thickness $(\mathrm{mm})$} \\
\hline & & & Mean & (S.E.) & Range \\
\hline \multicolumn{6}{|c|}{ Laboratory experiment $^{a}$} \\
\hline Controls & 14 & 66 & .218 & & $.180-.253$ \\
\hline Experimental (DDE) & 6 & 28 & $.189^{b}$ & & $.170-.205$ \\
\hline \multicolumn{6}{|l|}{ Field study ${ }^{c}$} \\
\hline $\begin{array}{l}\text { Pennsylvania } \\
\text { pre-1946 d }\end{array}$ & 37 & 37 & .241 & .003 & $.197-.277$ \\
\hline Ohio pre-1946 ${ }^{d}$ & 12 & 12 & .244 & .004 & $.230-.287$ \\
\hline $\begin{array}{l}\text { Ohio } 1973 \\
\text { (random, early)d }\end{array}$ & $\begin{array}{r}19 \\
8\end{array}$ & $\begin{array}{l}19 \\
16\end{array}$ & $\begin{array}{l}.234^{\mathrm{f}} \\
.243^{\mathrm{f}}\end{array}$ & $\begin{array}{l}.004 \\
.007\end{array}$ & $\begin{array}{l}.197-.260 \\
157-270\end{array}$ \\
\hline \multicolumn{6}{|c|}{$\begin{array}{l}{ }^{a} \text { Patuxent Wildlife Research Center (McLane and Hall, 1972). } \\
\text { b Significantly different from shell thickness of controls }(P<0.05) \text {. } \\
\text { c Klaas and Swineford (In preparation, Patuxent Wildlife Research Center). } \\
\text { dOne egg selected at random from each clutch in early stages of incubation, but } \\
\text { after clutch was completed. } \\
\text { e Unhatched eggs removed from nest after incubation was complete. Includes } 11 \\
\text { eggs from three clutches in which no eggs hatched. } \\
\text { f No statistical differences were detected in the means for the four groups of eggs. } \\
\text { t-test }(P>0.1) \text {. }\end{array}$} \\
\hline
\end{tabular}

\section{Residue Levels in Eggs}

The 19 fresh eggs collected early in the nesting season and an additional 16 addled eggs found in the same nests at the end of the 1973 nesting season were analyzed for chlorinated hydrocarbons (Klaas and Swineford, in preparation, Patuxent Wildlife Research Center). DDE and polychlorinated biphenyls (PCB's) were found in all 35 samples (Table 18), although the levels were generally low, as expected in view of the lack of eggshell thinning in the population (Table 17). Eight eggs in the sample (all from separate clutches) contained dieldrin (range 0.10-0.24 ppm).

Table 18. Residue levels of DDE and PCB's in 35 screech owl eggs collected in northern Ohio, 1973 (from Klaas and Swineford in preparation, ratuxent Wildlife Research Center).

\begin{tabular}{ccc} 
Category & $\begin{array}{c}\text { Arithmetic mean a } \\
\text { (ppm) }\end{array}$ & $\begin{array}{c}\text { Range } \\
\text { (ppm) }\end{array}$ \\
\hline DDE & 1.29 & $0.33-2.8$ \\
PCB & 1.32 & $0.26-3.4$ \\
\hline
\end{tabular}

\footnotetext{
a Wet weight.
} 
Numerous authors have stated that bird-eating and fish-eating raptors usually build up higher residues and have greater shell thinning than do rodent-eaters (review by Stickel 1973). Why did the screech owls, whose diets contained large quantities of migrant birds, not display these characteristics? We can only speculate that the lack of shell thinning and high egg residues in the Ohio population was because the eggs were laid before the predominance of avian prey became available to the owls. The owls just prior to and during the egg-laying period were feeding primarily on rodents. Thus, the seasonal pattern in the food habits of the screech owl may be offering the species some protection against the accumulation of high pesticide loads.

Eggs in three clutches contained the organochlorine pesticide mirex (three eggs in one clutch, mean $0.10 \mathrm{ppm}$, one egg in another clutch, $0.12 \mathrm{ppm}$, and one in another clutch $0.16 \mathrm{ppm}$ ). Mirex has stimulated considerable controversy during the past several years because of its actual and proposed widespread aerial application throughout the southeastern United States to control the imported fire ant (Solenopsis saevissima richteri). Recent laboratory studies by Heath and Spann (1973), however, showed no perceptible reproductive effects on bobwhite quail (Colinus virginianus) or mallards. Since mirex spray activities have been confined to the southeastern United States, we believe the screech owls in northern Ohio obtained their mirex from migratory passerine birds that wintered in the Southeast. The diet of screech owls during certain periods of the year consists mainly of migratory passerines (Table 2).

\section{POLYMORPHISM}

The existence of bimodal or polymodal variation within a species is referred to as polymorphism, in which intermediate forms occur at low frequency or are even absent (Owen 1963b). Polymorphism may be defined as the occurrence together in the same habitat of two or more distinct genetic forms of a species of animal or plant in such proportions that the rarest of them cannot be maintained by recurrent mutation (Ford 1940). Differences between the sexes, between young and older individuals, and among seasons are excluded from this definition. Hence, an extremely variable species may not necessarily be polymorphic. Huxley (1955) provided an outline for the analysis of polymorphism which included among other items: (1) the ecogeographical mapping of morph-frequency and determination of ratio-clines (if present, this should be repeated at regular intervals), (2) experimental and statistical 
evaluation of viability and other intrinsic or extrinsic selective advantages of the morphs concerned, and (3) genetical analysis of the underlying balance and stability mechanisms. In evaluating polymorphism in the screech owl, we attempt to follow the outline presented by Huxley.

The existence of two distinct color forms of the screech owl has been known since about 1874 when Ridgway (Baird et al. 1874) realized that rufous and gray birds were of the same species and that the forms were independent of age, sex, or season. Earlier, rufous and gray birds had been variously interpreted as belonging to different sexes or to different age classes (review by Hasbrouck 1893). Ridgway later published in many natural history and scientific journals an appeal for information on the frequency of rufous and gray birds, nesting information, and any other data that might help to solve the problem. The information was passed over to E. M. Hasbrouck who published an account of his findings (Hasbrouck 1893). A number of inaccuracies in Hasbrouck's paper were pointed out at the time in a critical review (Allen 1893). It was $70 \mathrm{yr}$ until another full survey of the geography of color forms in the screech owl was attempted (Owen 1963b), although several authors discussed small geographic areas (Martin 1950, Schorger 1954, Hrubant 1955).

Owen (1963b:189) summarized his description of geographical trends in the occurrence of color forms of the screech owl as follows:

"Throughout most of North America east of about $104^{\circ}$ there are two forms of the screech owl: one with the plumage mainly bright rufous and the other with the plumage mainly gray. Birds of intermediate coloration also exist, but in most areas they are rare. The relative frequency of rufous birds varies geographically in the form of a cline from north to south; about a quarter or less of the northern population is rufous, while in the south (the Gulf coast and Florida excepted) up to three quarters of the population may be rufous. . . The geography of polymorphism in the screech owl appears to be an unusual pattern of variation within an animal species."

Owen (1963b) indicated that the presence of polymorphism in the screech owl probably represents balanced adaptation of the forms to varying environmental conditions. After noting that the adaptive significance of the polymorphic forms was not understood, Owen indicated that a cline in the relative frequency of the forms as opposed to random or irregular distribution supports the view that polymorphism in the species is maintained by selection operating along environmental gradients. Fisher (1930) 
indicated that it is extremely unlikely that two or more very different phenotypes would be equally adapted to the environment in which they live; a balance of selective forces must be involved, for if not, one form would rapidly replace the other and there would be no polymorphism.

\section{Annual Variation in Color Phase Ratios}

Hasbrouck (1893) and Owen (1963b) studied the general patterns in the geographical occurrence of the two color phases of the screech owl. However, to explore the factors responsible for the patterns observed, we believed it would be fruitful to study yearly fluctuations in a given population, preferably one near the edge of its range. Although the screech owl's range extends into southern Ontario (Godfrey 1966), our study area in northern Ohio was sufficiently close to the northern edge of the range that yearly fluctuations were probable. During our 30-yr study, more than 4,000 observations of screech owls allowed us to assess fluctuations in the composition of the two morphs within the population.

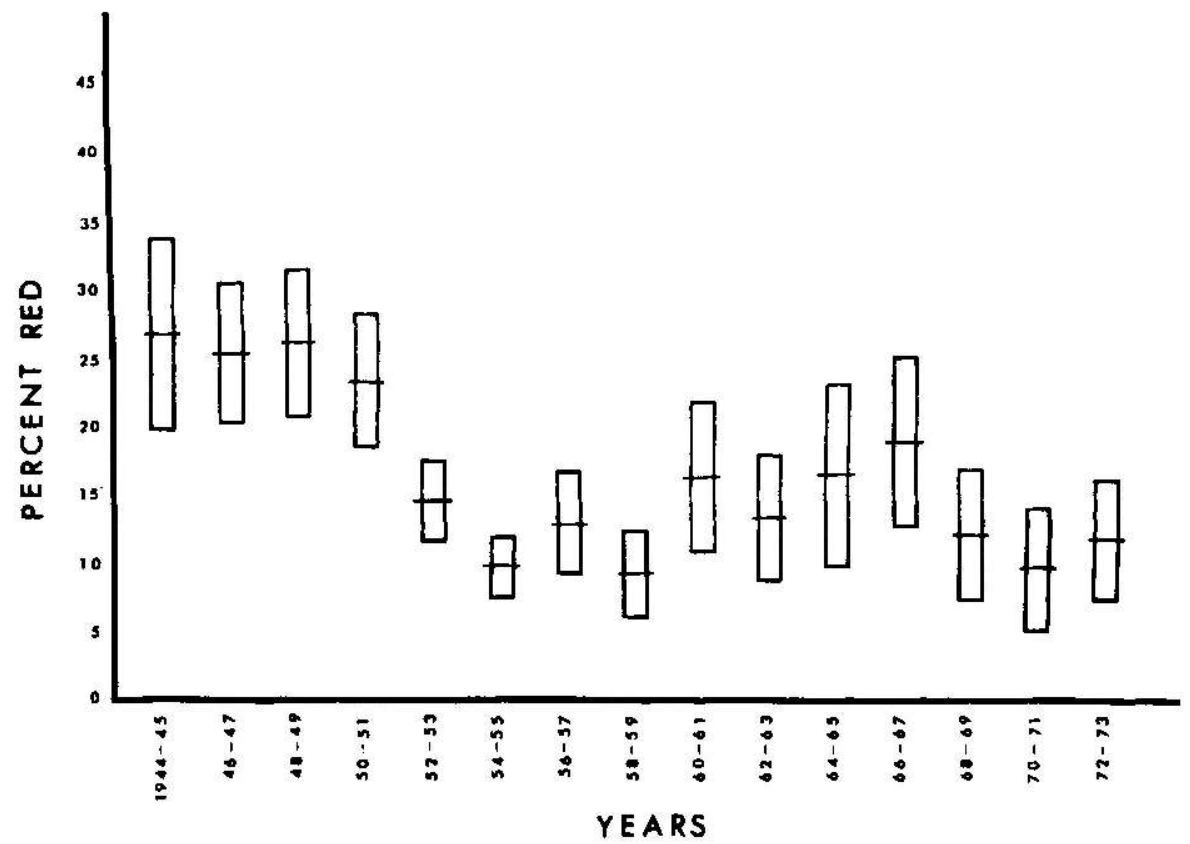

Fig. 8.-Changes in the color phase ratios of screech owls in the northern Ohio study area, 1944-73 (mean with $95 \% \mathrm{CI}$ ). 
The population during the first $8 \mathrm{yr}$ of the study (1944-51) consisted of about $25 \%$ red-phase birds. During December 1951, the percentage of reds decreased significantly (Table 19, Fig. 8). No significant annual change in the color phase ratio occurred during the remainder of the 30 -yr period, although the red phase seemed to increase slightly during the early and mid-1960's. Owen's (1963b) suggestion that environmental gradients were probably responsible for the clinal pattern observed in North America led us to review weather data. The Toledo weather station (Toledo Express Airport) is within the study area and monthly summaries for the 30 winters (November-April) were obtained for that station from the National Weather Records Center (Asheville, N.C.). The deepest snowfall during the 30-yr study occurred in December 1951 as a snowcover of $10.16 \mathrm{~cm}$ ( 4 in) or more lasted for 17 days, averaging $21.34 \mathrm{~cm}$ (8.4 in) (25.40 to $33.02 \mathrm{~cm}$ [10-13 in] on the ground for 6 days). The snow was accompanied by below-normal temperatures; the lows during the first 15 days of the snowcover averaged $-15 \mathrm{C}$ and for 4 days the temperature was below $-18 \mathrm{C}$.

Table 19. A summary of the color phase percentages of screech owls by 2-year periods in the Ohio study area. (Includes retrapped birds banded in previous years.)

\begin{tabular}{lrcccc}
\hline Years & $\begin{array}{c}\text { Percent } \\
\text { red }\end{array}$ & $\begin{array}{c}\text { Percent } \\
\text { gray }\end{array}$ & $\begin{array}{c}\text { Number } \\
\text { observations }\end{array}$ & $\begin{array}{c}\text { Standard } \\
\text { deviation }\end{array}$ & $\begin{array}{c}\text { Percent red } \\
\text { 95\% C.I. }\end{array}$ \\
\hline $1944-45$ & 26.8 & 73.2 & 149 & 3.63 & 19.7 to 33.9 \\
$1946-47$ & 25.5 & 74.5 & 267 & 2.67 & 20.3 to 30.7 \\
$1948-49$ & 26.2 & 73.8 & 267 & 2.69 & 20.9 to 31.5 \\
$1950-51$ & 23.3 & 76.7 & 275 & 2.55 & 18.3 to 28.3 \\
$1952-53$ & 14.7 & 85.3 & 537 & 1.53 & 11.7 to 17.7 \\
$1954-55$ & 9.8 & 90.2 & 695 & 1.13 & 7.6 to 12.0 \\
$1956-57$ & 13.0 & 87.0 & 300 & 1.94 & 9.2 to 16.8 \\
$1958-59$ & 9.3 & 90.7 & 323 & 1.62 & 6.1 to 12.5 \\
$1960-61$ & 16.5 & 83.5 & 176 & 2.80 & 11.0 to 22.0 \\
$1962-63$ & 13.6 & 86.4 & 206 & 2.39 & 8.9 to 18.3 \\
$1964-65$ & 16.7 & 83.3 & 120 & 3.40 & 10.0 to 23.4 \\
$1966-67$ & 19.2 & 80.8 & 156 & 3.15 & 13.0 to 25.4 \\
$1968-69$ & 12.3 & 87.7 & 179 & 2.46 & 7.5 to 17.1 \\
$1970-71$ & 9.8 & 90.2 & 174 & 2.25 & 5.4 to 14.2 \\
$1972-73$ & 11.9 & 88.1 & 218 & 2.19 & 7.6 to 16.2 \\
\hline
\end{tabular}


The combination of heaviest snowfall during the study and extremely cold weather seemed to be correlated with the only significant change in color phase ratios during the 3 decades. Thus, we hypothesize that heavy snowfall in combination with low temperatures plays a direct or indirect role in the relative abundance of the two morphs in the northern portion of the range. The gray phase, which is more abundant in the northern latitudes where winters are more extreme, seemed to survive the critical period much better than the red phase.

Retrap records of adult screech owls banded on the study area before the extreme winter provided information about relative survival of the two color phases during December 1951. Adult birds banded during 1947-50 were used in the analysis, and retrap records during 1952 or later were considered envidence of possible differential survival of the two morphs during the critical period of December 1951 (Table 20). This admittedly small sample suggests that $44 \%(10.8-6.0 / 10.8=44 \%)$ more red-phased birds than grays were lost during the interval which corresponds quite well with the drop in the ratio of reds from 1950-51 to 1952-53 (change from 23.3 to 14.7 , a drop of $37 \%[23.3-14.7 / 23.3=37 \%])$.

Table 20. A comparison of adult screech owls banded in 1947-50 and retrapped in 1952 or latter $a$.

\begin{tabular}{lll}
\hline \multicolumn{1}{c}{ Category } & Red & Gray \\
\hline Number banded & 50 & 157 \\
Number retrapped & 3 & 17 \\
Percentage retrapped & 6.0 & 10.8 \\
\hline
\end{tabular}

a Only banded birds retrapped at least once after banding were included (they may have been retrapped initially at any time).

A comparison between the two phases was then made for adult birds banded between 1953 and 1970 to determine if the gray phase birds were always retrapped at a higher rate than the red phase. The percentage of birds retrapped 2 or more yr after banding was nearly identical for both color phases during the 18-yr period (Table 21). This lends further support for our differential survival hypothesis for December 1951. Differential survival, of course, would lead to a change in the ratio of the two morphs. No significant change in the ratio of the two morphs was observed between 1952-53 and 1972-73 when each morph was retrapped in nearly identical percentages. 
Table 21. A comparison of adult screech owls banded in 1953-70 and retrapped 2 or more years after banding ${ }^{\text {. }}$.

\begin{tabular}{lcc}
\hline \multicolumn{1}{c}{ Category } & Red & Gray \\
\hline Number banded & 120 & 831 \\
Number retrapped & 9 & 65 \\
Percentage retrapped & 7.5 & 7.8 \\
\hline
\end{tabular}

${ }^{a}$ Only banded birds retrapped at least once after banding were included (they may have been retrapped initially at any time).

It is tempting to speculate about the population composition over the last 40 or $50 \mathrm{yr}$ in light of snowfall patterns. Based on records for the study area during the last $85 \mathrm{yr}$, snowfall was less than normal during 1920-50 and more than normal during the last $20 \mathrm{yr}$. The less than normal snowfall during the $25 \mathrm{yr}$ before the study began may have allowed the red phase to increase in abundance; then, the severe weather in December 1951 directly or indirectly seems to have caused a decrease in the red-phased segment of the population. The more than average snowfall during the next $20 \mathrm{yr}$ may be responsible for maintaining the population composition at the lower ratio of red to gray phases, although a hint was present that the red phase attempted to increase in abundance at times.

The ruffed grouse (Bonasa umbellus), another polymorphic species in North America, has a somewhat similar clinal pattern in color phase ratios (red and gray) within its range and some knowledge is available for this species. Gordon W. Gullion has worked for many years with survival rates of grouse, including survival related to color phase. Gullion and Marshall (1968:157) stated, "As a generalization, the prevalence of red-phase grouse in the population increases as the climate grades from the Arctic south. This suggests that the difference in mortality may be related to the severity of the winter; or more specifically, that there may be a color-linked susceptibility to cold or other climatic conditions, which selects against the red-phase grouse." Gullion (1966) indicated that during winters which lacked sufficient snow for burrowing, mortality among red-phase grouse was greater than among gray birds, but with better snow conditions the red-phase birds outlived the gray.

Gullion and Marshall (1968:157) indicated, "Earlier we believed that this differential survival represented periodically increased vulnerability to predation among red-phase birds (primarily as a result of insufficient burrowing snow), and we still cannot discount this idea entirely. ... We have suggested that the red-phase 
grouse may be more conspicuous to raptors hunting overhead than are the gray-phase birds." Thus, in summary, the increased mortality of the red-phase grouse may be due to a color-linked susceptibility to severe weather or a predation problem associated with color-linked vulnerability. The same conclusions seem to be applicable to the screech owl; in years of heavy snowcover, the red phase screech owls appear to be more prone to mortality because they have not developed the burrowing behavior of the ruffed grouse. The most important natural predator of the screech owl would probably be the great horned owl (Craighead and Craighead 1956), but we are doubtful that predators over a very short term could be responsible for the major change in color phase ratios in 1951. Lustick (1969) studied the effects of artificial radiation on bird energetics and concluded that radiant energy reduces oxygen consumption in birds and that the reduction is correlated with feather color, being greater in dark birds. Mosher and Henny (in press) recently conducted metabolic experiments with screech owls to attempt to ascertain the mechanism responsible for the change in color phase ratios in the population in 1951 by exposing birds of the two color phases to various temperature regimes. These data demonstrated a significant difference in oxygen uptake between color phases at -10 and $-5 \mathrm{C}$. This supports the hypothesis that redphase screech owls are restricted in their northern distribution by color related metabolic differences from the gray-phase birds. It also suggests that the extremely cold temperatures for a prolonged period of time in December 1951 were responsible for excessive mortality of red-phase birds.

\section{Sex, Age, and Color Phase}

Baird et al. (1874:51) first concluded that plumage color was independent of sex and age when they stated, "These two very different plumages are entirely independent of age, sex, or season, and that they are purely individual there can be no doubt, since in one nest there may often be found both red and gray young ones, while their parents may be either both red or both gray, the male red and the female gray, or vice versa." To our knowledge a large sample of birds from a given area has not been available to determine if the color is independent of sex. Hasbrouck (1893) presented data showing the relation of color to sex based on 646 birds from throughout the breeding range, but since it is doubtful that each sex was sampled equally throughout the species range, valid comparisons could not be made. Martin (1950) compared 75 study skins from Ontario and found no significant relationship 
between sexes and color phases. Similarly, we detected no significant relationship between sex and color phase in our sample of 760 nesting screech owls (Table 22). Fewer males were in the sample because they were often away from the nest at the time it was visited.

Table 22. The color phase composition of adult nesting screech owls, 1944-73 (includes pairs in which the male was unknown).

\begin{tabular}{lccc}
\hline & Gray & Red & Percent red $^{\text {a }}$ \\
\hline Males & 220 & 40 & 15.4 \\
Females & 403 & 97 & 19.4 \\
\hline
\end{tabular}

${ }^{a}$ No significant difference in color phase composition of nesting males and females (chi-square 1.87, 1 df NS). The intermediates were not included here.

The red and gray birds were found in almost identical ratios in both breeding populations and the young birds produced (Table 23). The intermediates were also consistent in both age categories (2.6 and 2.3\%).

Table 23. Classification of screech owl color morphs from northern Ohio. The data include only pairs in which the color phase of both parents was known. Percentages are in parentheses.

\begin{tabular}{|c|c|c|c|c|}
\hline Category & Red & Intermediate & Gray & Total \\
\hline \multicolumn{5}{|c|}{$1944-73$} \\
\hline Breeding population & $81(16.1)$ & $13(2.6)$ & $408(81.3)$ & $502(100.0)$ \\
\hline Offspring & $126(15.3)$ & $19(2.3)$ & $681(82.4)$ & $826(100.0)$ \\
\hline $\begin{array}{l}\text { Totals } \\
\text { Including }\end{array}$ & & & & \\
\hline $\begin{array}{l}\text { intermediates } \\
\text { Excluding }\end{array}$ & $207(15.6)$ & $32(2.4)$ & $1,089(82.0)$ & $1,328(100.0)$ \\
\hline intermediates & $207(16.0)$ & - & $1,089(84.0)$ & $1,296(100.0)$ \\
\hline \multicolumn{5}{|c|}{$1952-73$} \\
\hline Breeding population & $62(15.4)$ & $12(3.0)$ & $328(81.6)$ & $402(100.0)$ \\
\hline Offspring & $91(14.1)$ & $17(2.6)$ & $536(83.2)$ & $644(99.9)$ \\
\hline Totals & & & & \\
\hline $\begin{array}{l}\text { Including } \\
\text { intermediates } \\
\text { Excluding }\end{array}$ & $153(14.6)$ & $29(2.8)$ & $864(82.6)$ & $1,046(100.0)$ \\
\hline intermediates & $153(15.0)$ & - & $864(85.0)$ & $1,017(100.0)$ \\
\hline
\end{tabular}




\section{Genetic Hypotheses}

Hrubant (1955) analyzed screech owl data by the gene frequency method to test whether the matings occurred at random, and whether the offspring were produced in agreement with any of several genetic hypotheses. The genetic hypotheses tested were: (1) one pair of genes with dominance, (2) one pair of genes without dominance, (3) multiple alleles, and (4) sex associated inheritance. He concluded that lack of dominance may be dismissed as an acceptable mode of inheritance since neither of the ways in which this mode could be applied could account for the distribution of colors of the young produced and that none of the sex-associated modes are acceptable since the two attributes, color and sex, are independent of each other. This left Hrubant (1955) with but two modes of inheritance as possible explanations of the observed data. In testing the assumption of simple dominance, it was noted that red by red produce only red. Some grays were expected, but the lack of grays may be attributed to the small sample analyzed (only 10 offspring). Under the hypothesis of multiple alleles, the observed value of the intermediate class from red by gray matings deviated from the hypothetical value by a significant amount; however, small samples (only 10 offspring from red by red and 55 offspring from red by gray) made Hrubant's findings somewhat inconclusive.

\section{One Pair of Genes with Dominance}

Using the same approach as Hrubant, but with considerably larger sample sizes, we again tested the hypothesis of simple dominance. The method requires the assumption that the population is in equilibrium with respect to mating type, phenotype, and genotype. The significant change in color phase ratios between 1951 and 1952 suggested that the data collected during the first $8 \mathrm{yr}$ of the study (1944-51) should not be pooled with the latter data. Therefore, genetic hypotheses were tested with information collected during the last $22 \mathrm{yr}$ of the study (1952-73). To test this hypothesis the owls may be classified merely as red or gray, and the difference assumed to be caused by one pair of genes with the gene for red exhibiting dominance over the gene for gray. The intermediate owls may be regarded as misclassified gradations of the red and gray. Removal of the intermediates from the sample total in Table 23 leaves 864 gray and 153 red owls. Since an overwhelming number of the matings were gray by gray (Table 24), and since these matings produced only gray offspring, the gray phenotype may be assumed to be due to the recessive gene, and red due to its dominant allele. 
Table 24. Mating types of progeny of screech owls in northern Ohio with respect to color, 1952-73.

\begin{tabular}{|c|c|c|c|c|}
\hline \multirow{2}{*}{$\begin{array}{l}\text { Mating type } \\
\text { adult }\end{array}$} & \multirow{2}{*}{$\begin{array}{c}\text { Number of } \\
\text { successful } \\
\text { matings }\end{array}$} & \multicolumn{3}{|c|}{ Progeny } \\
\hline & & Red & Inter. & Gray \\
\hline 1. Red $\times$ red & 8 & 23 & 0 & 5 \\
\hline 2. Red × gray & 46 & 68 & 1 & 63 \\
\hline 3. Red × Inter. & 0 & 0 & 0 & 0 \\
\hline 4. Inter. × Inter. & 0 & 0 & 0 & 0 \\
\hline 5. Inter. $\times$ gray & 12 & 0 & 16 & 29 \\
\hline 6. Gray $\times$ gray & 135 & 0 & 0 & 439 \\
\hline Totals & 201 & 91 & 17 & 536 \\
\hline
\end{tabular}

Let $\mathrm{R}$ stand for the dominant gene for red pigment and $\mathrm{r}$ stand for its recessive allele for gray pigment. Let $p$ be the frequency of $r$ in the sample, such that $p+q=1$. Values of $q$ and $p$ may be obtained from the sample so that they are the maximum likelihood estimates of $\theta$ and $1-\theta$, the true frequencies of $r$ and $R$ in the population.

Following the discussion by Hrubant (1955), the estimates may be based upon the parents only, the offspring only, or upon the entire sample of $1,017 \mathrm{owls}$, omitting the intermediates. The entire sample of 1,017 appears to be the best choice since there is no marked evidences of heterogeneity within it and since the parents and offspring contain about the same frequencies of red and gray owls. Of 1,017 owls in the entire sample (omitting intermediates), 864 were gray. The frequency of $r$ thus $q=\sqrt{864 / 1,017}=0.9217$ and of $R$ is $p=0.0783$.

The theoretical mating type frequency, determined by the expansion of the binomial $((1-\theta)+\theta)^{4}$ using $q=0.9217$ as an estimate of $\theta$, and the observed mating frequencies are compared in Table 25. The data in this table show that the various kinds of matings occurred with frequencies in agreement with those expected if mating is at random. The computed chi-square is smaller (3.30) than the critical (5.99) at the $5 \%$ level of significance of 2 degrees of freedom. 
Table 25. Testing specific mating types of screech owls under hypothesis of one pair of genes with dominance.

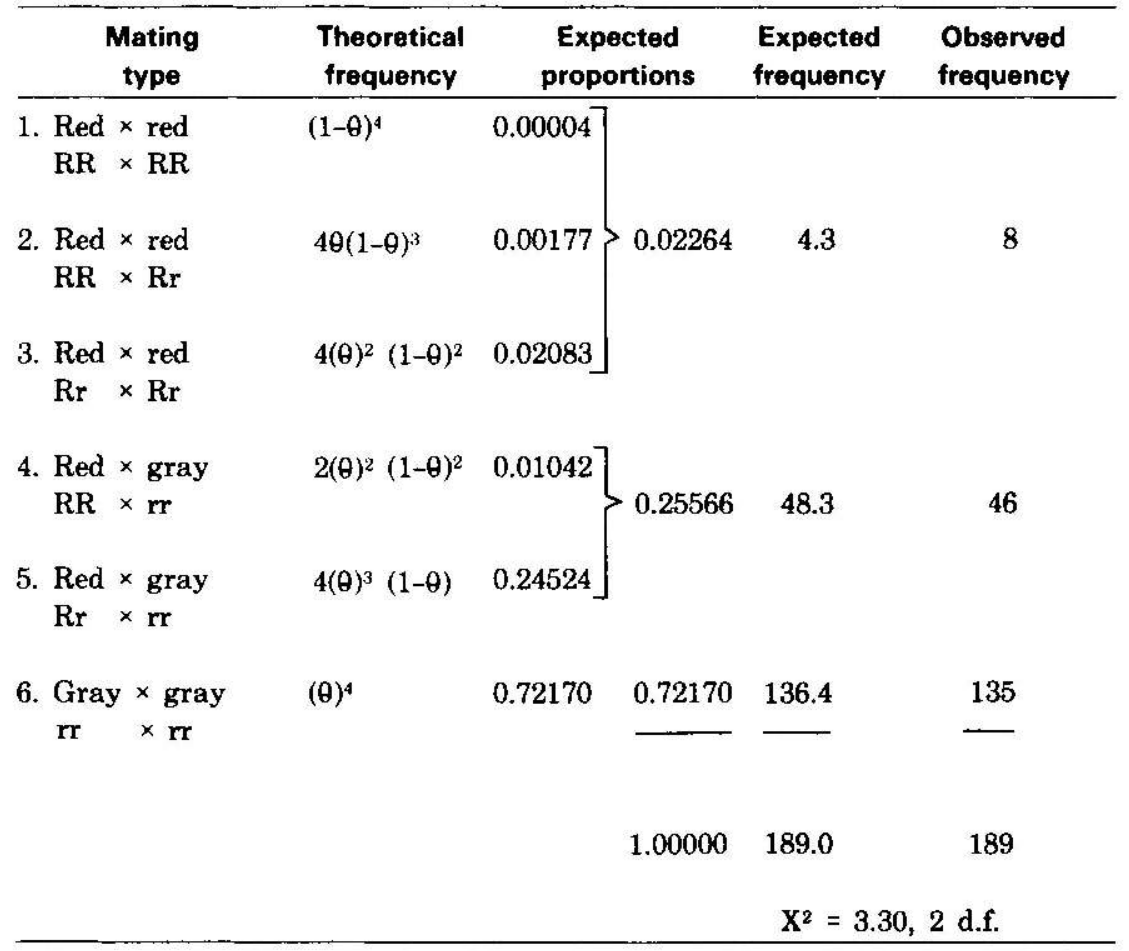

Table 26 contains the test of the observed distribution of young produced by individual mating types compared to their expected distribution. The expected numbers of offspring are found from the relative frequencies of the matings given in Table 25 . The data show that in all three mating combinations the observed numbers of offspring occur with frequencies in agreement with those calculated if the difference betwen red and gray is due to only one pair of genes with red dominant to gray. In fact, the observed and expected frequencies for red by gray and gray by gray are in complete agreement, whereas the red by red pairings are in nearly complete agreement (chi-square 0.22 ). The critical level for rejection of the hypothesis is 3.84 at the $5 \%$ level of significance for 1 degree of freedom. The observed data are nearly a perfect fit. 
Table 26. Distribution of young screech owls produced by mating phenotypes under hypothesis of one pair of genes with dominance.

\begin{tabular}{|c|c|c|c|c|c|}
\hline \multirow[b]{2}{*}{ Mating } & \multicolumn{2}{|c|}{$\begin{array}{c}\begin{array}{c}\text { Observed number } \\
\text { offspring }\end{array} \\
\end{array}$} & \multicolumn{3}{|c|}{$\begin{array}{c}\text { Expected number } \\
\text { offspring } \\
\end{array}$} \\
\hline & Red & Gray & Red & Gray & $x^{2}$ \\
\hline 1-3 Red × red & 23 & 5 & 21.6 & 6.4 & 0.22 \\
\hline 4-5 Red × gray & 68 & 63 & 68.2 & 62.8 & - \\
\hline 6 Gray × gray & 0 & 439 & 0 & 439.0 & - \\
\hline
\end{tabular}

\section{Multiple Alleles}

The other possible mode of inheritance (Hrubant 1955) is a multiple allelic system. Assume the red, intermediate, and gray phenotypes are inherited in this manner with a graded order of dominance of $Y$ (red) dominant to $y^{\prime}$ (intermediate) dominant to $y$ (gray). Table 27 illustrates the observed and expected sample frequencies and theoretical population frequencies used in deriving the values for the statistics $\mathrm{r}=0.0760, \mathrm{~s}=0.0152$, and $\mathrm{t}=0.9088$, as estimates of the true frequencies of genes.

Table 27. Sample frequencies and estimates of population gene frequencies of screech owls under hypothesis of a system of multiple alleles.

\begin{tabular}{|c|c|c|c|c|}
\hline & Genotype & $\begin{array}{l}\text { Theoretical } \\
\text { frequency }\end{array}$ & $\begin{array}{c}\text { Observed } \\
\text { frequency }\end{array}$ & $\begin{array}{l}\text { Expected } \\
\text { frequency }\end{array}$ \\
\hline YY & & $\mathrm{p}^{2}$ & & 0.0058 \\
\hline $\mathbf{Y y}^{\prime}$ & Red & $2 \mathrm{po}$ & 0.146 & 0.0023 \\
\hline Yy & & $2 \mathrm{p} \gamma$ & & 0.1381 \\
\hline $\mathbf{y}^{\prime} \mathbf{y}^{\prime}$ & & $\sigma^{2}$ & & 0.0002 \\
\hline & Inter. & & 0.028 & \\
\hline $\mathbf{y}^{\prime} \mathbf{y}$ & & $2 \sigma \gamma$ & & 0.0276 \\
\hline \multirow[t]{4}{*}{ yy } & Gray & $\gamma^{2}$ & 0.826 & 0.8259 \\
\hline & & $\mathrm{t}=\sqrt{8}$ & \multicolumn{2}{|c|}{$=0.9088$, frequency of $y(\gamma)$} \\
\hline & & \multicolumn{3}{|c|}{$s=\sqrt{864+29 / 1046}-0.9088=0.0152$, frequency of $y^{\prime}(\sigma)$} \\
\hline & & $r=1$ & \multicolumn{2}{|c|}{$=0.0760$, frequency of $Y(p)$} \\
\hline
\end{tabular}


The theoretical mating type frequency determined by the expansion of the trinomial $(p+\sigma+\gamma)^{4}$ and the observed mating type frequencies are compared in Table 28 . The data in this table show that the various kinds of matings occurred with frequencies in agreement with those expected if mating is at random. The computed chi-square (5.99) is smaller than the critical (11.07) at the $5 \%$ level of significance for 5 degrees of freedom; therefore, we concluded that the matings were at random.

Table 28. Testing specific mating types of screech owls under hypothesis of a system of multiple alleles.

\begin{tabular}{|c|c|c|c|c|}
\hline $\begin{array}{c}\text { Mating type } \\
\text { by phenotypes }\end{array}$ & $\begin{array}{l}\text { Theoretical } \\
\text { frequency }\end{array}$ & $\begin{array}{l}\text { Expected } \\
\text { proportions }\end{array}$ & $\begin{array}{l}\text { Expected } \\
\text { frequency }\end{array}$ & $\begin{array}{l}\text { Observed } \\
\text { frequency }\end{array}$ \\
\hline 1. Red $\times$ red & $\begin{array}{c}p^{4}+4 p^{3} \sigma+4 p^{3} \gamma+4 p^{2} \sigma^{2}+ \\
8 p^{2} \sigma \gamma+4 p^{2} \gamma^{2}\end{array}$ & 0.0213 & 4.3 & 8 \\
\hline $\begin{array}{l}\text { 2. Red } \times \text { gray } \\
\text { 3. Red } \times \text { inter. }\end{array}$ & $\begin{array}{l}2 p^{2} \gamma^{2}+4 p \sigma \gamma^{2}+4 p \gamma^{3} \\
2 p^{2} \sigma^{2}+4 p \sigma^{3}+12 p \sigma^{2} \gamma+\end{array}$ & 0.2415 & 48.5 & 46 \\
\hline & $4 p^{2} \sigma \gamma+8 p \sigma \gamma^{2}$ & 0.0081 & 1.6 & 0 \\
\hline 4. Inter. $\times$ inter. & $\sigma^{4}+4 \sigma^{3} \gamma+4 \sigma^{2} \gamma^{2}$ & 0.0008 & 0.2 & 0 \\
\hline 5. Inter. $\times$ gray & $2 \sigma^{2} \gamma^{2}+4 \sigma \gamma^{3}$ & 0.0460 & 9.2 & 12 \\
\hline 6. Gray × gray & $\gamma^{4}$ & 0.6821 & 137.1 & 135 \\
\hline & & 0.9998 & 200.9 & 201 \\
\hline & & & \multicolumn{2}{|c|}{$\mathrm{X}^{2}=5.99,5$ d.f. } \\
\hline
\end{tabular}

The observed distribution of young produced by the specific phenotypic mating types as compared to their expected distribution is shown in Table 29. The data show agreement in all cases between the frequencies of the observed numbers of offspring and those calculated if the difference between red, intermediate, and gray were due to a multiple allelic genetic system. This system involves a graded order of dominance of red over intermediate over gray. 
Table 29. Distribution of young screech owls produced by mating phenotypes under hypothesis of a system of multiple alleles.

\begin{tabular}{|c|c|c|c|c|c|c|c|}
\hline \multirow[b]{2}{*}{ Mating } & \multicolumn{3}{|c|}{$\begin{array}{l}\text { Observed numbers } \\
\text { offspring }\end{array}$} & \multicolumn{3}{|c|}{$\begin{array}{l}\text { Expected numbers } \\
\text { offspring }\end{array}$} & \multirow[b]{2}{*}{$x^{2}$} \\
\hline & Red & Inter. & Gray & Red & Inter. & Gray & \\
\hline 1. Red $\times$ red & 23 & 0 & 5 & 21.3 & 0.1 & 6.6 & 0.63 \\
\hline 2. Red $\times$ gray & 68 & 1 & 63 & 68.6 & 1.1 & 62.3 & 0.02 \\
\hline 3. Red $\times$ inter. & - & - & - & - & - & - & - \\
\hline 4. Inter. $\times$ inter. & - & - & - & - & - & - & - \\
\hline 5. Inter. × gray. & 0 & 16 & 29 & 0 & 22.3 & 22.7 & 3.53 \\
\hline 6. Gray $\times$ gray & 0 & 0 & 439 & 0 & 0 & 439.0 & - \\
\hline
\end{tabular}

Unfortunately then, neither of the two hypotheses of gene action (one pair of genes with dominance and multiple alleles) that appeared satisfactory to Hrubant (1955) can be eliminated on the basis of breeding data presented here. In fact, the evidence for the two hypotheses was strengthened by the new data as the expected values were in nearly perfect agreement with the observed breeding data. The fact that red by red produced approximately $25 \%$ grays was a most important finding because Hrubant noted that red by red produced only reds in his small sample. Therefore, the following hypotheses remain for the gene action: (1) If the intermediate phenotype is assumed to be due to genetic modifiers, the difference between red and gray is due to one pair of alleles, the gene for red exhibiting dominance over its allele for gray; (2) if all three colors are considered, the colors are inherited on the basis of a series of three alleles with a graded order of dominance of red $\rightarrow$ intermediate $\rightarrow$ gray.

\section{Brood Size and Color Phase}

Data were insufficient to provide a fledging rate estimate (per nesting attempt) for each color phase; however, a pooled estimate of the number of young fledged per successful nest was obtained. The color phase of both parents was documented for 211 successful nesting attempts during 1944-72 (Table 30). The data for 1973 were not included because one egg was taken from each nest for pesticide analysis. No significant difference in the number of young fledged for the various breeding combinations could be detected. 
Table 30. A summary of the estimated number of young screech owls fledged per successful nest for the various combinations of color phase pairs, 1944-72.

\begin{tabular}{|c|c|c|c|c|c|c|c|c|c|}
\hline \multirow[b]{2}{*}{ Category } & \multicolumn{6}{|c|}{ Young fledged } & \multirow{2}{*}{$\begin{array}{c}\text { Number } \\
\text { nests }\end{array}$} & \multirow{2}{*}{$\begin{array}{c}\text { Young fledged } \\
\text { per successful } \\
\text { nest }\end{array}$} & \multirow{2}{*}{ 95\% C.I. } \\
\hline & 1 & 2 & 3 & 4 & 5 & 6 & & & \\
\hline Gray $\times$ gray & 18 & 7 & 35 & 49 & 30 & 8 & 147 & 3.61 & $3.39-3.83$ \\
\hline Gray × red & 1 & 5 & 8 & 15 & 13 & 1 & 43 & 3.86 & $3.52-4.20$ \\
\hline Red $\times$ red & 1 & 0 & 1 & 4 & 3 & 0 & 9 & 3.89 & $3.06-4.72$ \\
\hline Inter. $\times$ gray & 1 & 0 & 1 & 5 & 3 & 1 & 11 & 4.09 & $3.32-4.86$ \\
\hline Inter. $\times$ red & 0 & 0 & 0 & 1 & 0 & 0 & 1 & 4.00 & - \\
\hline Total & 21 & 12 & 45 & 74 & 49 & 10 & 211 & 3.70 & \\
\hline
\end{tabular}

\section{STATUS OF POPULATION}

The status of any wildlife population may be evaluated in three general ways: (1) a complete count or direct enumeration on an annual basis, (2) an index to abundance at some time period during the life cycle, or (3) a life-equation approach which provides an indirect evaluation of the population's condition. These approaches are not new and fall within the general outline presented by Leopold (1933:139): “(1) Census (Measuring the Stock on Hand), and (2) Measuring the Productivity of the stock and comparing it with a standard." Furthermore, it is always useful to compare results obtained from several approaches. The complete count or direct enumeration of screech owls is impossible due to their habitat preferences. Therefore, we will rely upon an index to annual abundance and the life-equation approach to evaluate the status of the screech owl population in northern Ohio.

\section{Index to Annual Abundance}

The occupancy rate of wood duck boxes by screech owls during the nesting season may provide some insight into the relative annual abundance of the species on the study area. However, since the nest boxes were always placed in suitable habitat and loss of habitat has occurred on the study area (Table 1), the occupancy rate for nest boxes would provide only an index to abundance in suitable habitat. Thus, the possibility of an undetected decline due to loss of habitat exists. To further complicate the matter, we have been forced to use an index to annual abundance based on successful nests. This modification was necessary because during 
some years the boxes were visited early in the nesting season (a chance to observe nests that were later abandoned and unsuccessful), whereas in other years nests were visited only at banding time (successful nests only recorded). Therefore, because of the fluctuations in annual effort we believe that a more realistic annual comparison of abundance would be obtained from successful nests only.

Although indices based on wood duck box usage have many potential biases, two factors present during this study tend to minimize these biases: (1) the same observer checked the boxes annually, and (2) approximately the same number of boxes were available each year.

The information collected during the 30 -yr period suggested no long-term trend in abundance in suitable habitat, as measured by numbers of successful nests (Table 31). The 4 yr (1952-55) when students assisted in the study could not be evaluated because the number of nests checked was unknown. Excluding those $4 \mathrm{yr}$, the 10-yr indices to abundance were as follows: 1944-51, 10.1; 1956-63, 8.4; and 1964-73, 9.0. Successfully nesting screech owls were found annually in approximately $8.9 \%$ of the nest boxes during the 30-yr study. Assuming that $69.2 \%$ of the screech owl nesting attempts were successful (see section on BREEDING BIOLOGY), another $4.0 \%$ of the nest boxes were used annually, but without success, making a total of about $12.9 \%$ of the boxes utilized annually during the study. 
THE SCREECH OWL: LIFE HISTORY AND POPULATION ECOLOGY IN NORTHERN OHIO 57

Table 31. An index to the abundance of screech owls in suitable habitat in northern Ohio, 1944-73.

\begin{tabular}{|c|c|c|c|}
\hline Year ${ }^{a}$ & $\begin{array}{c}\text { No. of } \\
\text { boxes checked }\end{array}$ & $\begin{array}{l}\text { No. of } \\
\text { successful nests }\end{array}$ & $\begin{array}{l}\text { Percent with } \\
\text { successful nests }\end{array}$ \\
\hline 1944 & 45 & 4 & 9 \\
\hline 1945 & 78 & 4 & 5 \\
\hline 1946 & 95 & 6 & 6 \\
\hline 1947 & 128 & 14 & 11 \\
\hline 1948 & 133 & 11 & 8 \\
\hline 1949 & 139 & 15 & 11 \\
\hline 1950 & 140 & 24 & 17 \\
\hline 1951 & 145 & 10 & 7 \\
\hline Total 1944-1951 & 903 & 88 & $10.1^{b}$ \\
\hline 1956 & 210 & 20 & 10 \\
\hline 1957 & 208 & 14 & 7 \\
\hline 1958 & 190 & 14 & 7 \\
\hline 1959 & 180 & 12 & 7 \\
\hline 1960 & 155 & 11 & 7 \\
\hline 1961 & 140 & 9 & 6 \\
\hline 1962 & 130 & 18 & 14 \\
\hline 1963 & 125 & 11 & 9 \\
\hline Total 1956-63 & 1,338 & 109 & $8.4^{b}$ \\
\hline 1964 & 125 & 9 & 7 \\
\hline 1965 & 135 & 7 & 5 \\
\hline 1966 & 130 & 9 & 7 \\
\hline 1967 & 130 & 16 & 12 \\
\hline 1968 & 130 & 13 & 10 \\
\hline 1969 & 130 & 10 & 8 \\
\hline 1970 & 130 & 12 & 9 \\
\hline 1971 & 130 & 11 & 8 \\
\hline 1972 & 135 & 16 & 12 \\
\hline 1973 & 153 & 19 & 12 \\
\hline Total 1964-73 & 1,328 & 122 & $9.0^{b}$ \\
\hline Total 1944-73 & 3,569 & 319 & $8.9^{\mathrm{b}}$ \\
\hline
\end{tabular}

a Numbers of boxes checked in 1952-55 are unknown.

b Each year given equal weight. 


\section{Life Equation Approach}

A mathematical model showing the relations between population parameters that yield stable populations was developed by Henny et al. (1970). Information needed for the model includes (1) mortality rate schedules (obtained from recoveries of banded birds), (2) recruitment rates, and (3) age at sexual maturity. Estimates of these parameters have been presented in this paper for the screech owl.

We know that screech owls are capable of breeding at the end of their first year of life (as 1-yr-olds), although the percentage in this age class that breeds is not known with certainty. However, we still believe that the excercise in constructing a life-equation model is worthwhile, because it will point out future research needs and act as a check on the internal consistency of the input data. Adult mortality rate estimates for the screech owl range from 32.8 to $39.0 \%$ (Table 15), with a pooled estimate of $33.9 \%$. The mortality rate estimate for the first year of life was $69.5 \%$ (Table 15). The observed recruitment rate per breeding pair was estimated at between 2.55 (Table 13) and 2.63 based on the exposure-day method.

Initially, let us assume that all screech owls breed as 1-yr-olds, although we have some evidence that a portion of the 1-yr-olds do not nest. The estimated number of young that must be fledged per breeding-age pair to maintain a stable population may be estimated by the following formula (from Henny 1972):

$$
\overline{\mathbf{m}}=\frac{1-\mathbf{s}}{\mathbf{s}_{0}\left(1-\mathrm{s}+\mathrm{s}_{1}\right)}
$$

where

$\overline{\mathrm{m}}=$ the average number of female fledglings produced per breeding-age female $(2 \overline{\mathrm{m}}=$ the total number of young produced per breeding female assuming an equal sex ratio of fledglings)

$\mathbf{s}=$ third year and later survival rate

$s_{0}=$ first year survival rate

$\mathbf{s}_{1}=$ second year survival rate

By using the pooled estimate for adult mortality and assuming that all 1-yr-olds attempt to nest, it is estimated that only 2.22 young are required per breeding pair to maintain a stable population. This is slightly less than the observed recruitment (2.55 to 2.63$)$, and, although the mortality rates may not be precise, the modeling approach suggests that not all 1-yr-old screech owls need to attempt 
to nest annually in order to maintain a stable population. To pursue this matter a little further, let us assume for the moment that the recruitment rates and the mortality rates are correct and, through the modeling process, let us calculate the percentage of 1-yr-olds (solve for $p_{1}$ ) that must attempt to nest annually to balance the life equation (see Equation 1 in Henny 1972:6). Given the above constraints and assuming that 2-yr-olds and older attempt to nest each year, the population could remain stable if at least an average of $60 \%$ of the 1-yr-olds nested annually. This estimate is in farily close agreement with the 77 to $83 \%$ estimate based on a small sample of field data which may be biased upward.

\section{Summary of Status}

In summary, we believe that the screech owl population in northern Ohio has fluctuated in abundance during the last $30 \mathrm{yr}$, with no long-term trend being apparent in suitable habitat (Table 31). In addition, the recruitment rate observed during the long-term study seemed to be adequate to maintain the population numbers. We have indirect evidence that all 1-yr-olds are not required to nest (from modeling approach) and field evidence suggesting that a sufficient percentage of 1 -yr-olds are nesting. Furthermore, we have no evidence of eggshell thinning in the population (Table 17), although laboratory tests have shown that the species is susceptible to the eggshell thinning phenomenon. Residue levels of DDT and its metabolites along with PCB's were low (Table 18). It should be cautioned, however, that even though screech owls seem to be adaptable to people and their structures, continued habitat loss may gradually reduce the population numbers in northern Ohio as the woodlots and creek bottoms become cleared and farmed more intensively. The forested lands in the four-county study decreased $12 \%$ between 1958 and 1967. 


\section{SUMMARY}

1. The life history and population ecology of the screech owl was studied in northern Ohio between 1944 and 1973. The owls nested in boxes established for wood ducks. The birds were banded and periodically recaptured. Food habits, productivity information, and color phase of the parent birds and offspring were recorded.

2. The screech owl is an opportunistic feeder. The diet changes with the seasons of the year, i.e., during the nesting season migrant birds replace mammals in importance, and during the late summer insects become important.

3. There is no evidence from banding data to suggest that screech owls in the northeastern United States migrate.

4. Young screech owls begin dispersing from their natal areas in late summer or early fall, with only about one-fourth of the young birds remaining within $10 \mathrm{~km}(6 \mathrm{mi})$ of the banding site. On the contrary, adult birds remain close to the area where they previously nested.

5. The hypothesis of random dispersal distance in young screech owls was rejected. There appear to be two groups in the population: (1) a group showing little dispersal, and (2) a group wandering considerable distances.

6. The directional pattern of dispersal was random.

7. Pairs of screech owls were noted in the nest boxes in early February, but egg laying did not peak until about 15 March. Hatching takes place in mid-April to early May and most of the young leave the nest the last week of May or the first week in June.

8. The mean clutch size was 4.43 with a mean of 3.80 young fledged per successful nest. An estimated $69.2 \%$ of the nesting attempts were successful. Including unsuccessful nesting attempts, an estimated 2.55 to 2.63 young were fledged per breeding pair.

9. Annual variation in the number of young fledged per successful nest was small. The lack of variability was probably due to the predictable food source of passerine birds that migrated through the area each spring when young were in the nest. This contrasts with the highly variable productivity reported for owls dependent upon local cyclic rodent populations. 
10. Raccoon predation was implicated in a number of unsuccessful nesting attempts, but the overall effect of the raccoon on the screech owl population was not fully assessed.

11. The sex ratio in the population did not differ significantly from a 50:50 ratio.

12. The first year mortality rate of the screech owl was estimated at $69.5 \%$; adult mortality was estimated at $33.9 \%$.

13. Male and female screech owls banded as nestlings were known to nest successfully at the end of their first year of life (as 1-yrolds). Two estimates of the average proportion of 1-yr-olds nesting ranged from 77 to $83 \%$, but the percentage may be lower.

14. No significant eggshell thinning was detected in the population in 1973, and residue levels of DDE and PCB's were low.

15. In northern Ohio, the screech owl population consists mainly of a gray- and red-phased birds, but about 2 to $3 \%$ of the birds are intermediate in color.

16. A significant change in the ratio of red- to gray-phased birds occurred in December 1951. This change coincided with the lowest temperatures during the 30-yr study and the heaviest snowfall. The red-phased birds decreased from $23.3 \%$ of the population to $14.7 \%$. Additional evidence from retrap information suggests that the grays survived much better than the reds during the stressful period. The ratio of reds in the population failed to increase to pre-1951 levels during the next $20 \mathrm{yr}$.

17. No significant relationship existed between sex and color phase in our sample of 760 nesting screech owls.

18. The following hypotheses of gene action remain: (1) If the intermediate phenotype is assumed to be due to genetic modifiers, the difference between red and gray is due to one pair of alleles, the gene for red exhibiting dominance over its allele for gray; or (2) if all three colors are considered, the colors are inherited on the basis of a series of three alleles with a graded order of dominance of red $\rightarrow$ intermediate $\rightarrow$ gray.

19. No significant difference in brood size and color phase of the parents could be detected.

20. An index to annual abundance suggests that the screech owl population fluctuated in northern Ohio during the last $30 \mathrm{yr}$, but with no long-term trend apparent in available habitat. The life-equation approach also suggests that, over the long term, productivity probably balanced mortality. 


\section{ACKNOWLEDGMENTS}

The assistance of Michael Smith, Larry Shafer, Lee Garling, Denny Genzman, and Gene Walston in the field aspects of the study during the mid-1950's is appreciated. Informative discussions with Milton B. Trautman and Ronald L. Stuckey of the Ohio State University, and Theodore A. Bookhout of the Ohio Cooperative Wildlife Research Unit, led to the location of some interesting references concerning changes in the flora and fauna of the region. Kenneth P. Burnham of the Migratory Bird and Habitat Research Laboratory assisted in the analysis of directional dispersal, and Erwin E. Klaas of the Patuxent Wildlife Research Center conducted the pesticide analysis. William $\mathrm{H}$. Stickel of the Patuxent Widlife Research Center brought to our attention the vast food habit files that are stored at the Center. Richard D. Porter of the Denver Wildlife Research Center kindly reviewed the manuscript and Richard Wilmot reviewed the section concerning polymorphism. G. Ronald Austing and George Laycock provided several photographs to illustrate the publication. Our sincere thanks is expressed to all who assisted. 


\section{LITERATURE CITED}

Allen, A. A. 1924. A contribution to the life history and economic status of the screech owl (Otus asio). Auk 41(1):1-16.

Allen, J. A. 1893. Hasbrouck on "Evolution and dichromatism in the Genus Megascops." Auk 10(4):347-353.

American Ornithologists' Union 1957. Check-list of North American birds. Fifth Ed. Lord Baltimore Press. $691 \mathrm{pp}$.

Anderson, D. W. and J. J. Hickey 1972. Eggshell changes in certain North American birds. Proc. Int. Ornithol. Congr. 15:514-540.

Anonymous 1971. Ohio soil and water conservation needs inventory. Ohio Soil and Water Conservation Needs Committee. Columbus, Ohio (sponsored by U.S. Dep. Agric.). pp.14-15.

Baird, S. F., T. M. Brewer, and R. Ridgway 1874. A history of North American birds. Vol. 3. Little, Brown and Co., Boston, $560 \mathrm{pp}$.

Bellrose, F. C. 1955. Housing for wood ducks. Ill. Nat. Hist. Surv., Circ. 45 (rev.). 48 pp.

Bellrose, F. C., T. G. Scott, A. S. Hawkins, and J. B. Low 1961. Sex ratios and age ratios in North American ducks. Ill. Nat. Hist. Surv. Bull 27(6):391-474.

Bent, A. C. 1938. Life histories of North American birds of prey. U.S. Natl. Mus. Bull. 170 (Repr. by Dover Publ. Co., N.Y. 1961). 482 pp.

Burton, J. A., ed. 1973. Owls of the world: their evolution, structure and ecology. E. P. Dutton Co., New York. $216 \mathrm{pp}$.

Campbell, L. 1968. Birds of the Toledo area. The Blade, Toledo, Ohio. $330 \mathrm{pp}$.

Carpenter, F. H. 1883 . Screech Owls breeding in confinement. Ornithol. and Oologist 8(12):93-94.

Craighead, J. J. and F. C. Craighead, Jr. 1956. Hawks, owls, and wildlife. Stackpole Co., Harrisburg, $\mathrm{Pa} .443 \mathrm{pp}$.

Dice, L. R. and W. E. Howard 1951. Distance of dispersal by prairie deer mice from birthplace to breeding sites. Contri. Lab. Vertebr. Biol. Univ. Mich. 50:1-15.

Diller, O. D. 1962. More land in trees. The Ohio Farmer. May 5. p. 29, 49.

Emlen, J. T., Jr. 1940. Sex and age ratios in survival of the California quail. J. Wildl. Manage. 4(1):92-99.

Errington, P. L. 1932. Food habits of southern Wisconsin raptors, Part I. Owls. Condor 34(4):176-186.

Fisher, A. K. 1893. Hawks and owls of the U.S. U.S. Dep. Agric., Div. Ornithol. Mammal., Bull. 3:163-174.

Fisher, R. A. 1930. The genetical theory of natural selection. London, Oxford Univ. Press. $291 \mathrm{pp}$.

Ford, E. B. 1940. Polymorphism and taxonomy. Pages 493-513 in J. Huxley, ed. The New Systematics. Clarendon Press, Oxford. 583 pp.

Frazar, A. M. 1877. The mottled owl as a fisherman. Bull. Nuttall Ornithol. Club 2(2):80.

French, N. R., T. Y. Tagami, and P. Hayden 1968. Dispersal in a population of desert rodents. J. Mammal. 49(2):272-280.

Godfrey, W. E. 1966. The birds of Canada. Natl. Mus. Can. Bull. Biol. Ser. 73, 203. Queen's Printer, Ottawa. 428 pp. 
Gullion, G. W. 1966. The use of drumming behavior in ruffed grouse population studies. J. Wildl. Manage. 30(4):717-729.

Gullion, G. W. and W. H. Marshall 1968. Survival of ruffed grouse in a boreal forest. Living Bird 7:117-167.

Hasbrouck, E. M. 1893. Evolution and dichromatism in the genus Megascops. Am. Nat. 27(6-7):521-533, 638-649.

Heath, R. G. and J. W. Spann 1973. Reproduction and related residues in birds fed mirex. Inter- Am. Conf. Toxicol. Occup. Med. 8:421-435.

Heath, R. G., J. W. Spann, and J. F. Kreitzer 1969. Marked DDE impairment of mallard reproduction in controlled studies. Nature 224(5214):47-48.

Henny, C. J. 1972. An analysis of the population dynamics of selected avian species. U.S. Fish Wildl. Serv., Wildl. Res. Rep. 1. 99 pp.

Henny, C. J. and W. T. VanVelzen 1972. Migration patterns and wintering localities of American ospreys. J. Wildl. Manage. 36(4):1133-1141.

Henny, C. J., W. S. Overton, and H. M. Wight 1970 . Determining parameters for populations by using structural models. J. Wildl. Manage. 34(4):690-703.

Hickey, J. J. 1952. Survival studies of banded birds. U.S. Fish Wildl. Serv., Spec. Sci. Rep. Wildl, 15.177 pp.

Hickey, J. J., ed. 1969. Peregrine falcon populations their biology and decline. Univ. of Wisconsin Press, Madison. $596 \mathrm{pp}$.

Hickey, J. J. and D. W. Anderson 1968. Chlorinated hydrocarbons and eggshell changes in raptorial and fish-eating birds. Science 162(3850):271-273.

Howard, W. E. 1960. Innate and environmental dispersal of individual vertebrates. Am. Midl. Nat. 63(1):152-161.

Hrubant, H. E. 1955. An analysis of the color phases of the eastern screech owl, Otus asio, by the gene frequency method. Am. Nat. 89(4):223-230.

Huxley, J. 1955. Morphism in birds. Acta Inter. Ornithol. Congr. (1954) 11:309-328.

James, R. F. and N. D. Martin 1950. A study of screech owls in southern Ontario. Can. Field Nat. 64(5):177-180.

Johnston, R. F. 1956. Population structure in salt marsh song sparrows. Part I. Environment and annual cycle. Condor 58(1):24-44.

Kaatz, M. R. 1953. The settlement of the Black Swamp of northwestern Ohio. Northwest Ohio Q. 25:23-36, 134-156, 201-217.

Kelso, L. H. 1944. Behavior of the eastern screech owl(Otus asio naevius). Biol. Leafl. 23. Cornell Univ. 7 pp.

Kelso, L. H. 1950. The post juvenile molt of the northeastern screech owl. Biol. Leafl. 50. Cornell Univ. 3 pp.

Korschgen, L. J. and H. B. Stuart 1972. Twenty years of avian predator-small mammal relationships in Missouri. J. Wildl. Manage. 36(2):269-282.

Lack, D. 1966. Population studies of birds. Clarendon Press. Oxford. $341 \mathrm{pp}$.

Lack, D. 1968. Ecological adaptations for breeding in birds. Methuen \& Co., Ltd., London. 409 pp.

Leopold, A. 1933. Game management. Charles Scribner's Sons. New York. $481 \mathrm{pp}$.

Lidicker, W. Z., Jr. 1962 . Emigration as a possible mechanism permitting the regulation of population density below carrying capacity. Am. Nat. 96(1):29-33.

Lockie, J. D., D. A. Ratcliffe, and R. Balharry 1969. Breeding success and organochlorine residues in golden eagles in west Scotland. J. Appl. Ecol. 6(3):381-389.

Longcore, J. R., F. B. Samson, and T. W. Whittendale, Jr. 1971. DDE thins eggshells and lowers reproductive success of captive black ducks. Bull. Environ. Contam. Toxicol. 6(6):485-490. 
Lustick, S. 1969. Bird energetics: effects of artificial radiation. Science 163(3865):387-390.

Marshall, J. T., Jr. 1967. Parallel variation in north and middle American screech owls. West. Found. Vertebr. Zool., Monogr. 1. 72 pp.

Martin, N. D. 1950. Colour phase investigations on the screech owl in Ontario. Can. Field Nat. 64(6):208-211.

Mayfield, H. 1961. Nesting success calculated from exposure. Wilson Bull. 73(3):255-261.

Mayfield, $H$. 1962. Changes in the natural history of the Toledo region since the coming of the white man. Jack-Pine Warbler 40(2):36-52.

McDowell, R. D. and L. A. Luttringer, Jr. 1948. Pennsylvania birds of prey. Pa. Game Comm., Harrisburg. 32 pp.

McLane, M.A.R. and L. C. Hall 1972. DDE thins screech owl eggshells. Bull. Environ. Contam. Toxicol. 8(2):65-68.

Mosher, J. A. and C. J. Henny. (In Press) Thermal adaptiveness of plumage color in screech owls. Auk 94.

Murray, B. G., Jr. 1967. Dispersal in vertebrates. Ecology 48(6):975-978.

Owen, D.F. 1963a. Variation in North American screech owls and the subspecies concept. Syst. Zool. 12(1):8-14.

Owen, D. F. 1963b. Polymorphism in the screech owl in eastern North America. Wilson Bull. 75(2):183-190.

Ratcliffe, D. A. 1967. Decrease in eggshell weight in certain birds of prey. Nature 215(5097):208-210.

Ross, A. 1969. Ecological aspects of the food habits of insectivorous screech owls. Proc. West. Found. Vertebr. Zool. 1(6):301-344.

Schneider, W. 1937. Beringungsergebnisse an der mitteleuropaeischen Schleiereule (Tyto alba guttata Brehan). Vogelzug 8:159-170.

Schorger, A. H. 1954. Color phases of the screech owl between Madison, Wisconsin, and Freeport, Illinois. Auk 71(2):205.

Sherman, A. R. 1911. Nest life of the screech owl. Auk 28(2):155-168.

Sitterley, J. and J. Falconer 1933. Type of farming areas in Ohio. Ohio State Univ. and Ohio Agric. Exp. Stn. Bull. 56 (mimeo).

Stewart, P. A. 1952. Dispersal, breeding behavior, and longevity of banded barn owls in North America. Auk 69(3):227-245.

Stewart, P. A. 1969. Prey in two screech owl nests. Auk 86(1):141.

Stickel, L. F. 1973. Pesticide residues in birds and mammals. Pages 254-312 in C.A. Edwards, ed. Environmental pollution by pesticides. Plenum Press, London and New York. $x+542$ pp.

Stupka, A. 1953. Some notes relating to the mortality of screech owls in Great Smoky National Park. Migrant 24(1):3-5.

Sutton, G. M. 1927. Mortality among screech owls of Pennsylvania. Auk 44(4):563-564.

Trautman, M. B. 1940. The birds of Buckeye Lake, Ohio. Misc. Publ. Mus. Zool. Univ, Mich. 44. 466 pp.

Treat, W. E. 1889. A fishing screech owl. Auk 6(2):189-190.

Vaughan, R. 1961. Falco eleonorae. Ibis 103a:114-128.

Wallace, G. J. 1963. An introduction to ornithology. Second Ed. MacMillan, New York. $491 \mathrm{pp}$.

Wiemeyer, S. N. and R. D. Porter 1970. DDE thins eggshells of captive American kestrels. Nature 227(5259):737-738.

Wilson, K. A. 1938. Owl studies at Ann Arbor, Michigan. Auk 55(2):187-197. 